\title{
16
}

\section{Carbon in the Deep Biosphere}

\author{
Forms, Fates, and Biogeochemical Cycling \\ SUSAN Q. LANG, MAGDALENA R. OSBURN, AND ANDREW D. STEEN
}

\subsection{Introduction}

The form, fate, and biogeochemical cycling of carbon in subsurface environments impacts and reflects microbial activity and has important implications for global elemental fluxes. Photosynthetically derived organic matter $(\mathrm{OM})$ is transported to a depth where it can continue to fuel life far from solar inputs. Alternative energy-yielding reactions such as the oxidation of minerals and reduced gases can fuel life in the rocky subsurface of both the ocean and continents, altering the distribution and characteristics of carbon compounds. Nonbiological reactions such as the precipitation of calcium carbonate influence the availability of dissolved inorganic carbon for lithoautotrophs and, simultaneously, the carbon cycle over geologic time. The abundances, characteristics, and distributions of carbon in the subsurface can therefore provide an integrated history of biotic and abiotic processes and a template for interpreting similar patterns from other planetary bodies.

The goal of this chapter is to compile insights from disparate environments in order to build a mechanistic understanding of the controls on carbon abundance and distribution in the subsurface. The sections below summarize what is known from the oceanic and continental subsurface, realms that are often studied separately. We synthesize commonalities across these environments, highlight what remains unknown, and propose ideas for future directions.

One challenge with working across the marine-continental divide is that the terminology used to describe organic carbon varies between the two. We will use the following terms and abbreviations: particulate organic carbon (POC), dissolved organic carbon (DOC), and dissolved inorganic carbon (DIC). Another discrepancy between communities is in the use of units, with $\mathrm{ppm}$ or $\mathrm{mg} / \mathrm{L}$ dominating the continental literature and $\mu \mathrm{M}$ or $\mathrm{mM}$ in the marine literature. We will use molar units throughout for comparison's sake. Finally, while the soil community has moved away from the terms "refractory" and "recalcitrant" OM, they are still common in the marine community. Here, these terms refer to OM that has escaped remineralization due to its inherent molecular structure, physical associations with minerals, energetically unfavorable conditions, or the lack of a specific microbial community adapted to carry out the necessary degradative processes. 


\subsection{Oceanic Sedimentary Subsurface}

Approximately $1.68 \times 10^{14} \mathrm{~g}$ of organic carbon per year are buried in marine and estuarine sediments (1). Burial of organic carbon in sediments represents a transfer of reducing equivalents from Earth's surface to the subsurface, thereby allowing persistence of oxidized compounds such as $\mathrm{O}_{2}$ at the surface (2). The rate of burial of organic carbon in marine sediments therefore has an important influence on the redox state, and thus habitability, of Earth's surface.

Broadly, marine sediments can be divided into river and estuarine delta systems, continental shelves and slopes, and abyssal plains (Figure 16.1). Sediments may be more finely divided into provinces based on microbial community composition, grain size, OM content, and benthic communities, among other variables (3).

The oxidation of organic carbon in sediments is carried out by a series of heterotrophic organisms. Macrofauna have their greatest influence on the surface sediments of continental shelfs, while the role of meiofauna and microorganisms increases with depth and where oxygen is limited (4). Remineralization within anoxic sediments is dominated by microorganisms and is most prevalent at temperatures below $\sim 80^{\circ} \mathrm{C}$, constituting $\sim 75 \%$ of Earth's total sediment volume of $3.01 \times 10^{8} \mathrm{~km}^{3}(5)$. The composition, abundance, and activity of heterotrophic microorganisms in marine sediments therefore has a strong influence on the burial rate and chemical nature of organic carbon. While these reactions are catalyzed by enzymes, they are ultimately controlled by thermodynamics. This section will briefly review the chemical and biological factors that regulate organic carbon oxidation and burial rates, as well as some of the models that can be constructed to describe and predict those rates.

The burial rate of organic carbon in marine sediments is controlled by a range of biological and geological processes, including sedimentation rate, primary productivity, biological activity, sediment organic carbon content, chemical and physical form of organic molecules, and concentrations of oxidants (electron acceptors), as described below and in several reviews and syntheses (6-13). These factors are interrelated: rapid sedimentation rates influence the quality of OM delivered to the sediment surface, which in turns affects oxidation rates, oxygen exposure time (OET), quantity and composition of heterotrophic microbial communities, and concentrations of potential electron acceptors.

\subsubsection{Chemical Composition}

$\mathrm{OM}$ is delivered to marine sediments from marine sources such as sinking plankton and consumers and from terrigenous sources such as plant litter and soil OM. The chemical composition of fresh biomass is relatively well constrained and consists predominately of carbohydrates, proteins, and lipids. The composition of terrestrial material transferred by fluvial or aeolian processes ranges from fresh biomass to highly degraded and altered material. Lignin phenols synthesized solely by vascular plants have long been used to track 


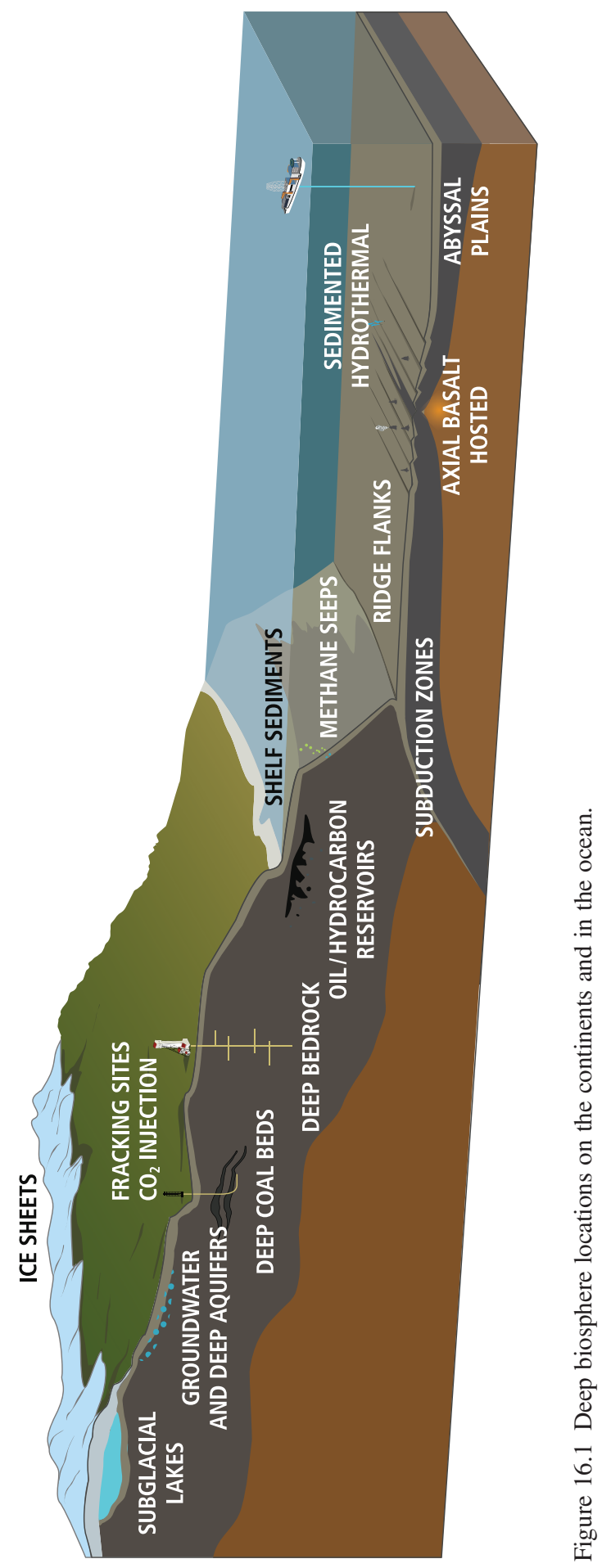


(a)
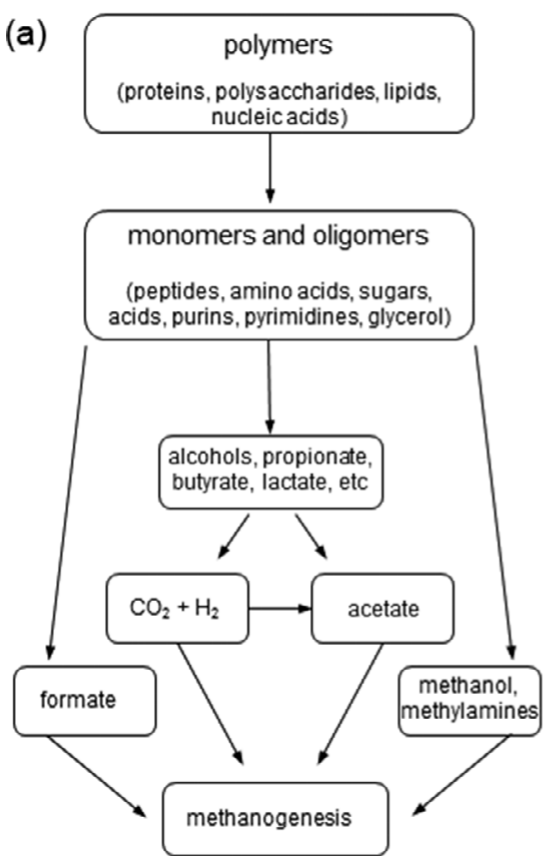

(b)

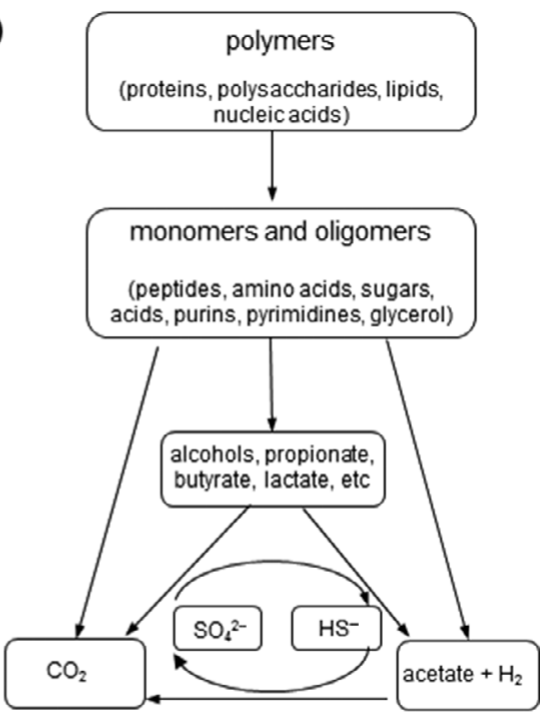

Figure 16.2 Anaerobic breakdown of $\mathrm{OM}$ by microorganisms via (a) methanogenesis and (b) sulfidogenesis.

Adapted from (25).

terrestrial inputs into the ocean (14). Ancient and recycled petrogenic carbon can also be remobilized from the weathering of sedimentary rocks (15). This suite of compounds is subject to biotic and abiotic alteration en route to marine deposition, which further diversifies the range of organic compounds present. Physical processes within the catchment are a major control on the composition and reactivity of OM delivered to the ocean by rivers (16), with larger inputs of both recently synthesized and ancient petrogenic organic carbon delivered in regions of higher erosional rates such as small mountainous streams (10,17-19) and some Arctic rivers (20-23).

Within the sediments, heterotrophic organisms and abiotic processes such as condensation reactions or sulfurization can alter the chemical structures of OM. In general terms, the heterotrophic remineralizaiton of larger organic molecules under anoxic conditions proceeds by the breakdown of polymers into monomers and oligomers, followed by smaller alcohols and organic acids, and finally methane and $\mathrm{CO}_{2}$ (Figure 16.2) (24,25). As a result, small organic molecules such as acetate, ethane, propane, and methane build up in the porewaters of anaerobic sediments, with additional contributions from acetogenesis and hydrogenotrophic methanogenesis (24,26-29).

Ultimately, the vast majority of OM produced in the upper water column is respired, with only $1 \%$ of gross primary production escaping remineralization to be buried in the 
deep sediments $(6-8,30)$. Some molecules survive due to chemical structures that are inherently recalcitrant, a process called "selective preservation." The role of this pathway is disputed. While some compounds such as highly cross-linked macromolecules are inherently less bioavailable than others, microorganisms are capable of metabolizing even ancient and highly altered OM relatively quickly under favorable conditions. Molecules may become less bioavailable due to nonbiological alteration. Abiotic sulfurization of organic molecules, deamination of peptides, and condensation of nitrogen-containing heterocyclic molecules all appear to promote the preservation of organics in sediments $(7,31)$. Random recombination of molecules or the production of altered metabolites by heterotrophic microorganisms can also rapidly convert labile organic carbon into far less reactive material $(32,33)$. Temperature can promote some of these transformations, as discussed in detail in Section 16.4.

\subsubsection{Bulk Controls on OM Preservation}

In locations with relatively rapid sediment accumulation rates such as river deltas and continental shelf sediments, greater OM preservation is most closely associated with higher mineral surface areas and shorter OETs $(7,34)$. These factors have proven broadly predictive of organic carbon distributions, although they do little to reveal the underlying mechanisms of preservation, nor do they allow for predictions of future responses to changing environmental conditions.

A prevailing paradigm is that microorganisms access POC only after it has been solubilized into DOC (35). Organic molecules enter cells via general uptake porins, which can only accommodate molecules in the size range of 600-1000 Da (36). Organic molecules in seawater, sediment porewater, and soils that are larger than $1000 \mathrm{Da}$ are, however, more bioavailable than small molecules on average (37-40), apparently because smaller molecules tend to be more extensively modified than larger molecules (41). Therefore, microbial extracellular enzymes appear necessary for the uptake and utilization of the most bioavailable organic carbon in sediments. Consistent with this paradigm, extracellular enzyme activity has been observed in deep, old sediments, including 217,000-year-old Mediterranean sapropels $(42,43)$ and Baltic Sea sediments that are up to 10,000 years old (44).

Several findings complicate the view that extracellular enzymes catalyze the ratelimiting step in biological organic carbon oxidation. Extracellular enzyme activities can outstrip the ability of sediment microbes to take up hydrolysate on timescales of days to years, leading to accumulations of apparently bioavailable low-molecular-weight DOM (45). Further, cells do not exclusively take up organic compounds via general uptake porins. Active transporters, for instance, use energy gradients to pass specific molecules through the cell membrane. These can be extremely large: for instance, certain TonBdependent transporters can import intact proteins up to $69 \mathrm{kDa}$ (46). Additionally, in seawater and in cow rumen, some cells are able to take up larger oligosaccharides into their periplasm, store them over extended periods, and then metabolize them when 
conditions are right $(47,48)$. The extent to which these mechanisms are important in sediments is not known, but temporal decoupling between macromolecule hydrolysis and metabolism could have implications for the dynamics of sediment OM oxidation.

\subsubsection{Sorption}

It has been observed for nearly 40 years that the volume-specific quantity of mineral surface area in sediments is correlated with organic carbon content (49). The mechanism underlying this relationship is not precisely understood. Sediments tend to accumulate quantities of organic carbon that are roughly equivalent to the amount that would be required to cover minerals in an organic monolayer $(50,51)$. Sedimentary organic carbon, however, exists in discrete "blebs" (Figure 16.3), so the fact that the average quantity of $\mathrm{OM}$ per unit of mineral surface area is roughly monolayer equivalent appears to be essentially coincidental (52).

Several mechanisms appear responsible for the protection of OM by mineral surfaces. First, OM may be occluded between mineral grains, within minerals themselves, or even within a matrix of more recalcitrant sorbed organic compounds $(53,54)$. Encased OM represents a sterile microenvironment in which biological oxidation is impossible. Second, even when sorbed $\mathrm{OM}$ is physically accessible to microorganisms, sorption slows or halts the diffusion of organic compounds to cell membranes (55). Finally, sorption distorts the physical structure of extracellular enzymes, preventing them from functioning normally, while simultaneously protecting enzymes from degradation and thereby substantially extending their active lifetimes (56,57). Associations with iron oxides, which include
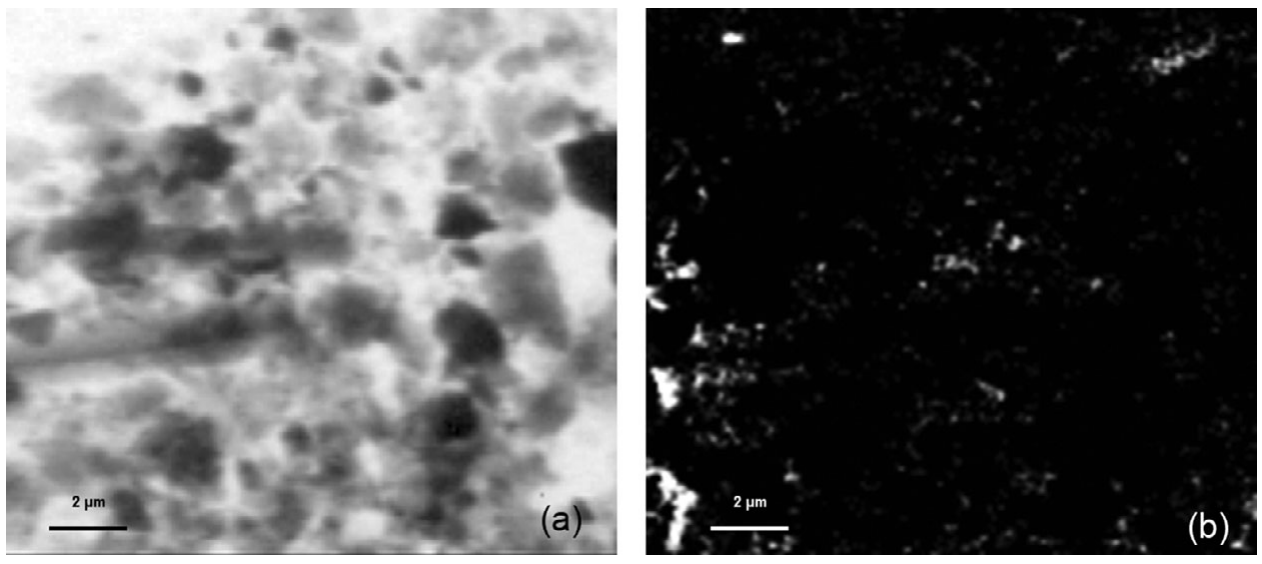

Figure 16.3 (a) Scanning transmission X-ray microscope image and (b) optical density map of the organic carbon distribution of sediments from $1.75 \mathrm{~m}$ below seafloor at Integrated Ocean Drilling Program Site 1231 Hole B, Peru Basin. The optical density map was generated by subtracting a preedge $\mathrm{X}$-ray image from a post-edge $\mathrm{X}$-ray image; brighter pixels correspond to higher concentrations of organic carbon. OM associated with particles is not distributed evenly over the surface.

Image courtesy of Dr. E. Estes, University of Delaware. 
chelation, coprecipitation, and noncovalent bonding to oxide surfaces, accounts for an average of $20 \%$ of organic carbon in sediments $(58,59)$. A full understanding of the mechanisms of microbial OM oxidation in sediments requires consideration of both the interactions between organic carbon and sediment minerals and the effects of mineral surfaces on the metabolisms of microorganisms.

\subsubsection{Oxygen Exposure Time}

Typical marine sediments underlying oxygenated seawater contain oxic porewater near the sediment-water interface, which becomes anoxic with increasing depth due to heterotrophic organic carbon oxidation. The depth of the oxic layer can vary dramatically, from millimeters or less in rapidly accumulating, organic-rich sediments to meters in ocean gyres. The presence of oxygen enhances the remineralization of organic molecules (60-62), and the term "oxygen exposure time" was coined to quantify the average time that sedimentary $\mathrm{OM}$ is exposed to "oxic" conditions, which can range from days to thousands of years $(8,34,62,63)$. Organic carbon oxidation is substantially faster in oxic sediments than anoxic sediments because the greater free energy of reaction of organic carbon with oxygen allows for a denser microbial community capable of catalyzing faster oxidation and because specific reactions (e.g. the oxidation of lignin via an oxygen radical intermediate) are not possible, or are vastly slower, in the absence of molecular oxygen (64). Thus, shorter exposure times are associated with higher organic carbon burial efficiencies and the preservation of less degraded materials $(7,8,13,34,63,65,66)$. This correlation is not absolute, however. Large provinces of ocean sediment underlying gyres are oxic to the basement, representing as much as 86 million years of OET (67). In such sediments, sedimentation rates are exceedingly slow and the sediments are very organic poor, and most oxidation apparently occurs directly at the sediment-water interface. Organic carbon oxidation in "rich" anoxic systems such as rapidly accumulating estuarine sediments can exceed $100 \mu \mathrm{M} \mathrm{C}$ day $^{-1}$, primarily via sulfate reduction, compared with $\sim 3$ $\times 10^{-6} \mu \mathrm{M} \mathrm{C}$ day $^{-1}$ in oxic gyre sediments.

\subsubsection{Models of Organic Carbon Diagenesis}

Due to the chemical complexity of sedimentary OM, sedimentary diagenetic models have focused on the transformation of bulk organic carbon to $\mathrm{CO}_{2}$. One common class of models assumes the following form:

$$
r=-\frac{d G}{d t}=\sum_{i=1}^{n} k_{i} G_{i},
$$

where $r$ is the bulk rate of $\mathrm{CO}_{2}$ production, equivalent to the rate disappearance of bulk organic carbon $(G)$, which in turn is the sum of the oxidation rates of different carbon pools $\left(G_{i}\right)$, each of which is oxidized according to a different, characteristic rate constant $\left(k_{i}\right)$ (68). Frequently, these "multi- $G$ " models only include two or three reactivity classes of 
OM: usually a fast-reacting "labile" pool, an unreactive "recalcitrant" pool, and sometimes an intermediate "semi-labile" pool. Related models include the reactivity-continuum model, which assumes an infinite number of reactivity pools $(69,70)$, and that of Middelburg (71), in which a single time-dependent reactivity rate constant is assumed. These models are mathematically straightforward, but they are somewhat mechanistically disconnected from the reality of sediment OM, which is tremendously chemically complex $(7,72)$.

Recently, models that include a broader set of parameters, such as microbial biomass, enzyme substrate specificity, and temperature-rate relationships, have been successfully employed in soils and sediments $(73,74)$. By including a wider range of processes, these models have the capacity to both quantitatively fit bulk organic carbon concentration data and make reasonable predictions about systems' likely responses to changing environments.

\subsection{Oceanic Rocky Subsurface}

Below ocean sediments, the igneous ocean crust hosts $\sim 2 \%$ of the total volume of the ocean, making it the largest aquifer system on Earth (75). Seawater actively circulates through this aquifer and drives the transfer of heat and elements between fluids and rocks with ramifications for ocean chemistry (76-79) and for the thermal, physical, and geochemical structure of the crust and mantle $(80,81)$. Microbial life is widespread in the rocky oceanic subsurface and both exploits and influences these exchanges (82-84), altering the abundance and form of carbon. Fluid flow through the rocky subsurface is ultimately driven by a source of heat such as cooling magma or hot rocks $(80,85)$. Heated fluids rise buoyantly and ultimately exit the sub-seafloor, drawing cool seawater into the crust to replace it.

The carbon characteristics of the fluids and rocks in hydrothermal systems and the igneous basement differ greatly depending on the type of host rock, the temperature of the system, and the presence or absence of sediments. Some systems are further influenced by factors such as phase separation, magma injections, seismic activity, extent of subduction, and even tides (86-89). Below, carbon transformations are described in some of the primary types of hydrothermal circulation systems (Figure 16.4).

\subsubsection{Characteristics of Recharge Water}

The chemical composition of the seawater that enters into the rocky subsurface has a strong influence on subsequent water-rock and microbial reactions. Deep seawater carries DIC in concentrations of 2.1-2.3 mM (90) and DOC in concentrations of $\sim 34-48 \mu \mathrm{M}(2,91)$. DOC is composed of a complex set of molecules, some of which turnover rapidly on timescales of hours to years. The majority of DOC, however, is slow to remineralize and has the potential to be stored for millennia in the ocean's interior (see (92) for review). Refractory 


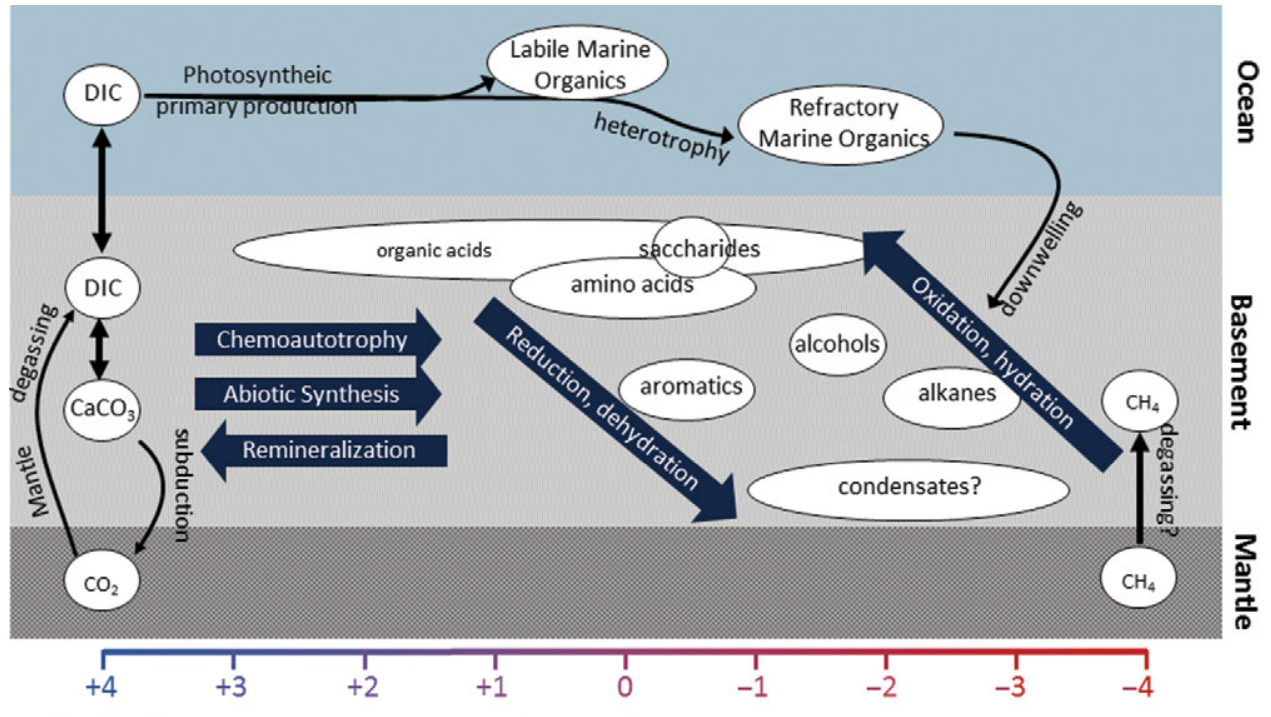

Oxidized

Carbon Oxidation State

Reduced

Figure 16.4 The abundance and composition of organic molecules in hydrothermal fluids will reflect a complex reaction history. While chemoautotrophy and abiotic synthesis involve the reduction of inorganic carbon into organic molecules, remineralization will do the reverse. Oxidation and dehydration reactions produce smaller, more polar compounds that are generally more labile and more easily consumed by heterotrophic microorganisms. Reduction and dehydration reactions may produce larger and more apolar material that is more resistant to microbial degradation and may be sequestered in the subsurface or persist for long periods of time in the deep ocean.

DOC is highly degraded, has few recognizable biomarkers, and has a ${ }^{14} \mathrm{C}$ age of 4000-6000 years, substantially longer than the mixing time of the ocean (93). DOC isolated from seawater and subjected to nuclear magnetic resonance and Fourier-transform ion cyclotron resonance mass spectrometry is composed primarily of carboxyl-rich aliphatic matter (94), acylated polysaccharides (95), and carotenoid degradation products (96) (see (97) for review).

\subsubsection{Axial High Temperature, Basalt Hosted}

The most widely recognized hydrothermal systems are close to axial spreading centers, where new injections of magma maintain high temperatures (Figure 16.1). The host rock is mafic and fluids exit through chimney structures at temperatures that can reach $>400^{\circ} \mathrm{C}$ (98). Exiting fluids are rich in dissolved metals that, upon mixing with cold seawater, precipitate the sulfide minerals that give them the name "black smokers." In the water column, the hot fluids mix further with seawater, cool, reach neutral buoyancy, and spread away from the vent field. The chemical signatures from these plumes of water can be detected thousands of kilometers away from the field $(99,100)$. 


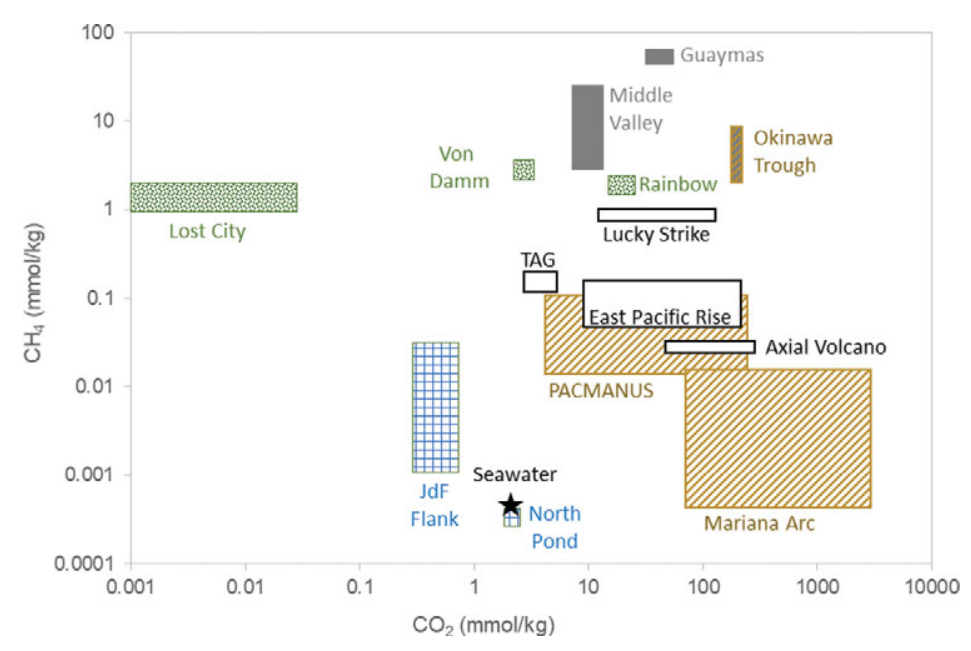

Figure 16.5 Range of methane and $\mathrm{CO}_{2}$ concentrations in basalt-hosted high-temperature (black outline; Axial Volcano, Trans-Atlantic Geotraverse (TAG), $9^{\circ} \mathrm{N}$ East Pacific Rise, Lucky Strike), ultramafic-hosted (green diamonds; Lost City, East Summit of Von Damm, Rainbow), ridge flank (blue checkers; Juan de Fuca ridge flank, North Pond), back-arc basins (orange diagonal; PACMANUS, Mariana Arc, Okinawa Trough), and sedimented systems (gray boxes; Guaymas, Middle Valley, Okinawa Trough). Seawater composition is included for comparison. Methane concentrations at North Pond are plotted at the reported detection limit of the analysis $(0.5 \mu \mathrm{M})$.

References are given in Table 16.1.

The majority of high-temperature vent fluids have DIC concentrations equal to or greater than deep seawater due to inputs of magmatic $\mathrm{CO}_{2}$ (Figure 16.5 and Table 16.1) (101). DIC concentrations are generally 3-30 mM, or they can be higher when fluids are impacted by phase separation, fresh inputs of magma, or sedimentary degradation (see (101) for review). Additions of magmatic $\mathrm{CO}_{2}$ are identified by $\delta^{13} \mathrm{C}$ isotopic signatures (-9\%o to $-4 \%$ ) $(102,103)$ that are markedly different from deep seawater DIC $(-0.5 \%$ to $1.0 \%)(104)$. The lack of ${ }^{14} \mathrm{C}$ in $\mathrm{CO}_{2}$ from some hydrothermal fluids demonstrates that the DIC carried with recharge water can be fully removed during sub-seafloor circulation in some cases (105). Calcium carbonate veins in basalts and gabbros have isotope values consistent with precipitation of marine DIC at the relatively low temperatures of seawater recharge $(106,107)$.

Methane concentrations in sediment-free, high-temperature axial fluids $(\sim 7-200 \mu \mathrm{M})$ are higher than those of seawater $(0.0003 \mu \mathrm{M})$, but generally low when compared to sedimented or ultramafic-influenced systems (Figure 16.5 and Table 16.1). For example, vent fluid $\mathrm{CH}_{4}$ concentrations range from 7 to $213 \mu \mathrm{M}$ from high-temperature vents from along the East Pacific Rise (111,123,147-150), while those from along the Mid-Atlantic Ridge (MAR) range from 8 to $147 \mu \mathrm{M}(98,117-119,151-153)$. Concentrations can spike as a result of volcanic eruptions and due to outgassing after a dike injection $(88,89,113)$.

The majority of the DOC carried with deep seawater is destroyed during circulation through mafic hydrothermal systems. The first evidence for this removal came from a study 
Table 16.1 Characteristics and carbon contents of representative oceanic sub-seafloor fluids.

\begin{tabular}{|c|c|c|c|c|c|c|c|c|}
\hline \multirow{2}{*}{$\begin{array}{l}\text { System type } \\
\\
\text { Example system }\end{array}$} & \multirow{2}{*}{$\begin{array}{l}\text { Seawater } \\
\text { Below } \\
1500 \mathrm{~m}^{a}\end{array}$} & \multicolumn{2}{|c|}{ Sedimentary porewater } & \multicolumn{3}{|c|}{$\begin{array}{c}\text { Basalt hosted, } \\
\text { unsedimented, } \\
\text { high temperature }\end{array}$} & \multicolumn{2}{|c|}{$\begin{array}{c}\text { Basalt hosted, } \\
\text { unsedimented, } \\
\text { diffuse/mixed fluids }\end{array}$} \\
\hline & & $\begin{array}{l}\text { Cascadia } \\
\text { Margin }^{b} \\
0-65 \text { mbsf }\end{array}$ & $\begin{array}{l}\text { Cascadia } \\
\text { Margin }^{b} \\
65-189 \text { mbsf }\end{array}$ & $\begin{array}{l}\text { East Pacific } \\
\text { Rise }\left(9^{\circ} 50^{\prime} \mathrm{N}\right)^{c}\end{array}$ & $\begin{array}{l}\text { Axial } \\
\text { Volcano }^{d}\end{array}$ & $\mathrm{TAG}^{e}$ & $\begin{array}{l}\text { East Pacific } \\
\text { Rise diffuse } \\
\left(9^{\circ} 50^{\prime} \mathrm{N}\right)^{f}\end{array}$ & $\begin{array}{l}\text { Axial } \\
\text { Volcano }^{8}\end{array}$ \\
\hline Temperatures $\left({ }^{\circ} \mathrm{C}\right)$ & $2-5$ & $\leq 9$ & $\sim 8-12$ & $275-371$ & $217-328$ & $290-321$ & $23-55$ & $3-78$ \\
\hline $\mathrm{pH}\left(\right.$ at $\left.23^{\circ} \mathrm{C}\right)$ & 7.8 & $7.7-8.0$ & $7.7-8.4$ & $3.5-4.2$ & $3.5-4.4$ & $3.1-3.5$ & $5.8-6.4$ & $4.6-5.8$ \\
\hline $\mathrm{H}_{2}(\mathrm{mM})$ & 0.0003 & - & - & $0.27-8.4$ & $<0.1-0.8$ & $0.10-0.37$ & $\begin{array}{l}\text { BDL- } \\
0.0058\end{array}$ & $<0.5$ \\
\hline $\begin{array}{l}\text { Dissolved } \\
\text { iron }(\mu \mathrm{M})\end{array}$ & $<0.001$ & - & - & $8-5150$ & $12-1065$ & $1640-5170$ & $<2-277$ & $35-400$ \\
\hline$\Sigma \mathrm{CO}_{2}(\mathrm{mM})$ & $2.1-2.3$ & $7-24$ & $18-29$ & $9.4-219$ & $50-285$ & $2.9-5.0$ & $3.0-11.8$ & - \\
\hline$\delta^{13} \mathrm{C}_{\mathrm{CO} 2}(\%)$ & -0.6 to 0.4 & $\begin{array}{l}-24.4 \text { to } \\
25.6\end{array}$ & $27.9-33.6$ & -4.2 to -3.7 & - & -13.0 to -6.9 & -4.2 to -2.2 & - \\
\hline $\mathrm{F}^{14} \mathrm{C}_{\mathrm{CO} 2}$ & $0.7511-0.9677$ & - & - & - & - & - & - & - \\
\hline $\mathrm{CH}_{4}(\mathrm{mM})$ & 0.0003 & BDL-69 & $71-236$ & $0.05-0.16$ & 0.025 & $0.12-0.16$ & $0.003-0.500$ & $<0.6$ \\
\hline$\delta^{13} \mathrm{C}_{\mathrm{CH} 4}(\%)$ & - & $-59.7 \pm 7.1$ & $\begin{array}{l}-46.7 \text { to } \\
-41.7\end{array}$ & -34.6 to -16.8 & - & -9.5 to -8.0 & - & - \\
\hline $\mathrm{F}^{14} \mathrm{C}_{\mathrm{CH} 4}$ & - & - & - & - & - & - & - & - \\
\hline $\begin{array}{l}\Sigma\left(\mathrm{C}_{2} \mathrm{H}_{6}-\mathrm{C}_{4} \mathrm{H}_{8}\right) \\
(\mu \mathrm{M})\end{array}$ & BDL & $0-35 \operatorname{ppmv}^{q}$ & $\begin{array}{l}0.5-7318 \\
\text { ppmv }^{q}\end{array}$ & - & - & - & - & - \\
\hline$\delta^{13} \mathrm{C}_{\mathrm{C} 2 \mathrm{H} 6, \mathrm{C} 4 \mathrm{H} 8}(\%)$ & - & - & - & - & - & - & - & - \\
\hline $\mathrm{CO}(\mu \mathrm{M})$ & BDL & - & - & BDL-2.0 & - & BDL & $5.7-17.8$ & - \\
\hline $\mathrm{CH}_{3} \mathrm{SH}(\mathrm{nM})$ & BDL & - & - & $2.4-4.9$ & - & 12 & - & - \\
\hline DOC $(\mu \mathrm{M})$ & $35-45$ & $400-3200$ & $1700-5100$ & - & $8-24$ & - & - & $34-71$ \\
\hline$\delta^{13} \mathrm{C}_{\mathrm{DOC}}(\%)$ & -20 to -22 & $\begin{array}{l}-23.6 \text { to } \\
-22.1\end{array}$ & $-20.2 \pm 0.4$ & - & - & - & - & -18.6 \\
\hline $\mathrm{F}^{14} \mathrm{C}_{\mathrm{DOC}}$ & $0.444-0.767$ & - & - & - & - & - & - & $0.481^{r}$ \\
\hline Formate $(\mu \mathrm{M})$ & BDL & - & - & - & - & - & - & - \\
\hline Acetate $(\mu \mathrm{M})$ & BDL & $5-57$ & $14-89$ & - & - & - & - & - \\
\hline $\begin{array}{l}\text { Hydrolizable } \\
\text { amino acids }(\mu \mathrm{M})\end{array}$ & $80-160$ & - & - & - & - & - & - & - \\
\hline
\end{tabular}

"_" is used where no reports available in the literature.

$\mathrm{BDL}=$ below detection limit; $\mathrm{mbsf}=$ neters below seafloor; $\mathrm{TAG}=$ Trans-Atlantic Geotraverse

${ }^{a}(93,104,108,109)$.

${ }^{b}(29,110)$.

${ }^{c}(109,111-113)$.

${ }^{d}(114-116)$.

${ }^{e}(98,109,117-119)$.

${ }^{f}(109,111,120)$.

$g(86,114,116,121)$.

${ }^{h}(109,122-126)$.

${ }^{i}(127)$.

${ }^{j}(116,128-133)$.

${ }^{k}(134,135)$

${ }^{l}(109,136)$.

${ }^{m}(109,119,137-139)$.

${ }^{n}(109,112,140-143)$.

${ }^{o}(144)$.

$p(145,146)$.

${ }^{q}$ Headspace gas concentrations in equilibrium with sediments.

${ }^{r} \mathrm{~F}^{14} \mathrm{C}$ of ultrafiltrated DOC (>1000 Da). 


\begin{tabular}{|c|c|c|c|c|c|c|c|c|}
\hline \multicolumn{2}{|c|}{$\begin{array}{l}\text { Basalt hosted, } \\
\text { sedimented, high } \\
\text { temperature }\end{array}$} & \multirow{2}{*}{$\begin{array}{c}\begin{array}{c}\text { Ridge Flank } \\
\text { ("warm") }\end{array} \\
\text { Juan de Fuca } \\
\text { Ridge Flank }{ }^{j}\end{array}$} & \multirow{2}{*}{$\begin{array}{l}\begin{array}{l}\text { Ridge Flank } \\
\text { (“cool”) }\end{array} \\
\text { North Pond } \\
\text { Basement }^{k}\end{array}$} & \multicolumn{2}{|c|}{$\begin{array}{l}\text { Ultramafic influenced, } \\
\text { high temperature }\end{array}$} & \multirow{2}{*}{$\begin{array}{r}\begin{array}{r}\text { Ultramafic } \\
\text { dominated }\end{array} \\
\text { Lost City }^{n}\end{array}$} & \multicolumn{2}{|c|}{$\begin{array}{c}\text { Silicic } \\
\text { back-arc }\end{array}$} \\
\hline $\begin{array}{l}\text { Guaymas } \\
\text { Basin }^{h}\end{array}$ & $\begin{array}{l}\text { Middle } \\
\text { Valley }^{i}\end{array}$ & & & $\begin{array}{l}\text { Von Damm } \\
\text { (East Summit) }{ }^{l}\end{array}$ & Rainbow $^{m}$ & & PACMANUS $^{\circ}$ & $\begin{array}{l}\text { Okinawa } \\
\text { Trough } \\
\text { (sedimented) }^{p}\end{array}$ \\
\hline $100-315$ & $40-281$ & 64 & $3.1-3.8$ & 226 & $350-367$ & $30-91$ & $152-358$ & $>220-320$ \\
\hline $4.5-6.1$ & - & 7.5 & $7.4-7.6$ & 5.6 & $2.8-3.4$ & $9-11$ & $2.3-4.7$ & $4.7-5.4$ \\
\hline $0.52-3.30$ & $1.9-8.2$ & $0.3-0.7$ & - & $18.2-19.2$ & $12.3-16.5$ & $1-14$ & $0.0084-0.306$ & 0.05 \\
\hline $17-180$ & - & $0.6-1.1$ & - & - & $23,700-24,050$ & $<3.5 \mu \mathrm{M}$ & $76-14,600$ & - \\
\hline $35-54$ & $8.2-13$ & $0.2-0.6$ & $2.0-2.4$ & 2.80 & $16.0-24.6$ & $0.0001-0.026$ & $4.4-274$ & 198-200 \\
\hline-9.4 & $\begin{array}{l}-34.6 \text { to } \\
-20.7\end{array}$ & -9.7 to -1.3 & $\begin{array}{l}-0.16 \text { to } \\
0.67\end{array}$ & $0.8-0.9$ & -3.15 to -2.5 & $\sim-9$ & -5.7 to -2.3 & -5.0 to -4.7 \\
\hline 0.056 & - & $0.083-0.233$ & $0.595-0.865$ & $0.0251-0.0373$ & - & - & - & - \\
\hline $44.2-58.8$ & $3.0-22.6$ & $0.001-0.030$ & $<0.0005$ & 2.81 & $1.6-2.5$ & $0.9-2.0$ & $0.014-0.085$ & $2.4-7.1$ \\
\hline-43.8 & $\begin{array}{l}-55.5 \\
\text { to }-50.8\end{array}$ & -58 to -23 & - & -15.6 to -15.3 & -17.7 to -15.8 & -13.6 to -9.3 & -20.8 to -7.4 & $\begin{array}{l}-41.2 \text { to } \\
-36.1\end{array}$ \\
\hline 0.077 & & - & - & $0.0056-0.0064$ & - & $0.0017-0.0062$ & - & - \\
\hline- & $14-310$ & - & - & 695 & 0.84 & $1.0-2.0$ & - & - \\
\hline- & $\begin{array}{l}-25.3 \text { to } \\
-18.7\end{array}$ & - & - & -12.9 to -9.8 & - & -16.0 to -13.0 & - & - \\
\hline $27-92.4$ & - & - & - & n.d. & $5.0-7.4$ & BDL & $0.006-0.17$ & - \\
\hline $11-10,000$ & - & - & - & 22 & $7.4-10.3$ & $1.4-1.9$ & - & - \\
\hline $111-2112$ & - & $11-18$ & $18-33$ & - & - & $68-106$ & - & - \\
\hline- & - & $\begin{array}{l}-34.5 \text { to } \\
-24.8\end{array}$ & $\begin{array}{l}-26.6 \text { to } \\
-23.9\end{array}$ & - & - & -21.0 to -10.5 & - & - \\
\hline- & - & $\begin{array}{l}0.166-0.230^{q} \\
0.186-0.204\end{array}$ & $0.352-0.472$ & - & - & - & - & - \\
\hline$<40$ & - & - & - & 88.2 & - & $36-158$ & - & - \\
\hline BDL-295 & - & - & - & - & - & $1-35$ & - & - \\
\hline 5.2 & - & $0.043-0.089$ & - & - & - & $0.7-2.3$ & - & - \\
\hline
\end{tabular}


of amino acids in the sediment-covered Guaymas Basin $(26,122)$. Concentrations of dissolved free amino acids in high-temperature fluids $\left(>150^{\circ} \mathrm{C}\right)$ were below detection limits and below deep ocean concentrations, with the losses attributed to the instability of organic compounds at high temperatures $(122,154)$. The DOC content of black smoker vents on the unsedimented portions of the Juan de Fuca spreading center is less than half that of deep seawater $(<17$ versus $36 \mu \mathrm{M})(116)$. Concentrations of DOC that can be isolated onto solid-phase extraction (SPE-DOC) phases are $~ 92 \%$ lower in unsedimented black smokers from Juan de Fuca and the MAR than in deep seawater (155). It is possible to experimentally reproduce losses of OM by heating $(125,155-157)$, though this does not conclusively rule out alternative removal mechanisms such as sorption onto mineral surfaces or heterotrophy.

\subsubsection{Axial Diffuse Vents, Basalt Hosted}

Adjacent to axial, high-temperature systems, local seawater enters the crust, creating "diffuse vents." The mixing of oxygenated seawater and reduced hydrothermal fluids results in chemical disequilibria that microorganisms can exploit for metabolic energy (158). Due to mixing and conductive cooling of fluids, temperatures are often well below the upper temperature limits of life $\left(122^{\circ} \mathrm{C}\right)(159)$. As a result, these zones are thriving subseafloor microbial habitats $(3,82,84,160,161)$. Microbial activity can alter fluid chemistry, resulting in losses of $\mathrm{H}_{2} \mathrm{~S}$ and $\mathrm{H}_{2}$ and gains of $\mathrm{CH}_{4}$ relative to high-temperature fluids $(111,112,115,162)$.

In diffuse vents on the Juan de Fuca Ridge, DOC is elevated over local deep seawater ( $\sim 7$ versus $36 \mu \mathrm{M})$, attributed in part to sub-seafloor autotrophic production (116). This DOC has a lower ${ }^{14} \mathrm{C}$ content and a more positive $\delta^{13} \mathrm{C}$ value than local seawater, consistent with a contribution of chemolithoautotrophs incorporating a pre-aged carbon source such as mantle $\mathrm{CO}_{2}(121)$.

\subsubsection{Ridge Flanks}

Fluid continues to flow through the rocky subsurface far from the ridge axis, as rocks cool in the absence of new magma injections (Figure 16.1). The extent of advective flow through these "ridge flank" systems can be determined from discrepancies between modeled conductive heat loss and heat flow measurements that indicate the convective flow of water in crust that is $0-65 \mathrm{Ma}(75,80)$. Sediment cover precludes fluid transport into and out of the crust; bare-rock seamounts are therefore the primary locations of advective transport (128). Even in regions with thick sedimentary layers, however, exchange of water, carbon, elements, and nutrients continues between deep sedimentary porewater and basement fluids.

Based on magnesium budgets, fluid fluxes through "cool" ridge flank systems $\left(<45^{\circ} \mathrm{C}\right)$ are substantially larger than those through warmer systems $(77,163)$. Cool basement fluids 
$\left(<20^{\circ} \mathrm{C}\right)$ have been accessed by Integrated Ocean Drilling Program drilling in the North Pond sedimented basin on the MAR (161). Dorado Outcrop on the Cocos Plate has also been confirmed to vigorously vent large quantities of water at temperatures of $10-20^{\circ} \mathrm{C}$ (164). The "warm" ridge flank system on the Juan de Fuca ridge has been intensely studied for decades, including via series of Ocean Drilling Program boreholes that have been drilled perpendicular to the ridge to allow direct access to the basement (165).

DIC is substantially lower in Juan de Fuca ridge flank fluids than in seawater $(0.1-0.9$ versus $2.6 \mathrm{mmol} / \mathrm{kg}$; Table 16.1), likely due to precipitation of calcium carbonate in the subsurface $(130,166,167)$. In contrast, fluids from the lower-temperature Dorado and North Pond systems have DIC concentrations that are similar to seawater $(134,164)$. In many cases, the $\delta^{13} \mathrm{C}$ values of DIC are lower than that of seawater, suggesting an input from remineralization of organic carbon or $\mathrm{CO}_{2}$ trapped in basaltic vesicles $(130,133,135)$. The apparent ${ }^{14} \mathrm{C}$ age of DIC is often used as a measure of fluid residence time, although this must be treated with caution, as mixing with older water masses, remobilization of calcium carbonate, input of basalt vesicle $\mathrm{CO}_{2}$, and remineralization of ${ }^{14} \mathrm{C}$-depleted $\mathrm{OM}$ can influence these signatures $(133,168-170)$.

Methane concentrations are low but detectable in Juan de Fuca ridge flank fluids (1-32 $\mu \mathrm{mol} / \mathrm{kg})(131,132)$. The isotopic signatures of methane $(-58.0 \%$ o to $-22.5 \%$ ) indicate a mixture of processes, including biogenic production and oxidation (132). Methane concentrations at North Pond were below detection (134).

DOC concentrations are lower than seawater in ridge flank fluids on the Juan de Fuca ridge and at North Pond (116,131,133-135). In both cases, this DOC has a lower ${ }^{14} \mathrm{C}$ content and $\delta^{13} \mathrm{C}$ signatures that are more negative than those of starting seawater $(121,133,135)$. This pattern was initially attributed to a complete removal of seawater DOC, followed by an input of chemosynthetically derived organic material (121). New data suggest that the isotopic signatures could instead be attributed to the selective oxidation and removal of portions of the seawater DOC pool $(133,135)$. Diffusion of porewater from the sediments covering the ridge flank may also contribute some organic compounds to the fluids (124), as this exchange impacts the inorganic chemistry $(129,131,165)$.

\subsubsection{Ultramafic Influenced}

Systems hosted on ultramafic rocks undergo water-rock reactions that are distinct from those of mafic environments. Ultramafic systems can be located on spreading centers and influenced by magmatic injections, but they can also be far from the spreading center or along ultra-slow-spreading centers with little to no magmatic influence. The compositional differences between ultramafic rocks derived predominantly from Earth's mantle and mafic rocks such as basalt and gabbro give rise to fluids with distinct chemical signatures. Fluids that have reacted peridotites are strongly enriched in $\mathrm{H}_{2}$ and $\mathrm{CH}_{4}$ and, in some cases, have drastically lower metal contents (Figure 16.5 and Table 16.1). 
The earliest recognitions of an ultramafic hydrothermal signature in the ocean came from high ratios of $\mathrm{CH}_{4}$ to $\mathrm{Mn}$ and suspended particulate matter in the water column on the MAR (171-173). Subsequently, the Logatchev, Rainbow, Menez Gwen, Ashadze, and Nibelungen hydrothermal fields were identified along the MAR, with fluid chemistries that exhibit a mixture of magmatic influences such as high temperatures $\left(200-372^{\circ} \mathrm{C}\right)$, acidic pHs $\left(2-4\right.$ at $25^{\circ} \mathrm{C}$ ), and high metal contents (e.g. millimolar concentrations of $\mathrm{Fe}$ and hundreds of micromolar concentrations of $\mathrm{Mn}$ ), but also ultramafic influences such as millimolar concentrations of $\mathrm{CH}_{4}$ and $\mathrm{H}_{2}$ (Table 16.1; for reviews, see 119,174). Peridotite-influenced systems have since been identified on the Mid-Cayman Rise $(136,175)$ and Marianas Forearc $(163,176)$. The ultramafic-dominated system in the Lost City Hydrothermal field has minimal interaction with magmatic processes, resulting in lower fluid temperatures $\left(40-91^{\circ} \mathrm{C}\right)$, alkaline pHs $\left(9-11\right.$ at $\left.23^{\circ} \mathrm{C}\right)$, and low metal contents $(<100 \mathrm{nM}$ of $\mathrm{Fe}$ and $<50 \mathrm{nM}$ of $\mathrm{Mn})(140,143,177)$. A magmatic influence is still evident, however, in elevated the ${ }^{3} \mathrm{He}$ content of fluids (112). Ultramafic-dominated, low-temperature, alkaline systems are also present in the shallow waters of Prony Bay in New Caledonia, fed by meteoric water (178), and on the Southern Mariana Forearc at the Shinkai Seep Field (179).

The inorganic carbon concentration in ultramafic-influenced systems is highly dependent on $\mathrm{pH}$ and magmatic inputs. In low-pH ultramafic systems, concentrations of $\Sigma \mathrm{CO}_{2}$ can reach as high as those observed in magmatic systems, at $\sim 4-20 \mathrm{mM}$ (Table 16.1; see (119) for a review). The $\delta^{13} \mathrm{C}$ values of this $\mathrm{CO}_{2}$ display "typical" midocean ridge values of $-4 \%$ to $-2 \%$ in some cases such as the Rainbow vent field (119). In other locations such as the Logatchev field, it is unusually positive, up to $+9.5 \%$, even in fluids with $\Sigma \mathrm{CO}_{2}$ concentrations higher than seawater $(119,180)$. In alkaline ultramafic systems such as Lost City, the high pHs lead to the rapid precipitation of calcium carbonate and therefore vanishingly low concentrations of $\Sigma \mathrm{CO}_{2}$ in endmember fluids $(112,140)$. This removal likely occurs throughout the fluid circulation pathway. Carbonate mineralization is common in ultramafic rocks (181), and isotope signatures indicate precipitation occurs both at cold seawater temperatures and at warmer $\left(65-95^{\circ} \mathrm{C}\right)$ temperatures, where $\delta^{13} \mathrm{C}$ values indicate that the source $\Sigma \mathrm{CO}_{2}$ has a substantial mantle component (107).

Methane concentrations in ultramafic systems are frequently an order of magnitude higher than those in unsedimented, basalt-hosted systems (Figure 16.5 and Table 16.1), and substantial methane anomalies along the MAR have been attributed to exports from these systems $(119,171-173)$. Estimates from mantle ${ }^{3} \mathrm{He}$ exports suggest serpentinization of ultramafic rocks could account globally for about $75 \%$ of the methane flux from midocean ridge systems (182). Isotopic signatures point to a nonbiological source for this methane $(112,119,183)$, although in most systems more $\mathrm{CH}_{4}$ is present than would be expected in thermodynamic equilibrium with $\mathrm{CO}_{2}$ (for reviews, see $(101,183)$ ). One possibility is that the methane was formed long ago, at higher temperatures than the present day, and is subsequently stripped from vesicles in the rocks $(136,184)$, which contain high $\mathrm{CH}_{4}$ and $\mathrm{CO}_{2}$ contents $(185,186)$. Biologically derived methane from 
methanogenesis may also contribute (187), albeit at relatively low levels when compared to the dominant nonbiological signature.

Short-chain hydrocarbons such as ethane, propane, and butane have been found in the low-micromolar concentrations in a wide range of ultramafic systems (Table 16.1) $(112,136,180)$. Isotopic values that decrease with increasing chain length have been used to demonstrate that these species are not derived from the decomposition of sediments and could have a nonbiological origin such as Fischer-Tropsch-type reactions (112). At the Lost City and Von Damm hydrothermal fields, the concentrations of these compounds increase in conjunction with methane concentrations $(112,136)$, indicating similar processes may lead to their formation and/or cycling.

Formate and acetate have been reported in elevated concentrations in multiple ultramafic systems including Lost City (formate: 36-158 $\mu \mathrm{M}$; acetate: 1-35 $\mu \mathrm{M}$ ) (141), Von Damm (formate: below detection to $669 \mu \mathrm{M}$ ) (136), and Prony Bay (formate: $\sim 4 \mu \mathrm{M}$; acetate: $\sim 70 \mu \mathrm{M}$ ) (188). At Lost City, the isotopic composition of formate indicates it is synthesized by two pathways: abiotic synthesis in the subsurface that results in ${ }^{14} \mathrm{C}$-free formate with a $\delta^{13} \mathrm{C}$ signature $(-13.0 \%$ o to $-8.9 \%$ ) similar to methane and short-chain hydrocarbons; and near-surface biological synthesis that incorporates modern DIC, resulting in formate with substantial ${ }^{14} \mathrm{C}$ and a more positive $\delta^{13} \mathrm{C}$ signature $(-9.1 \%$ o to 4.3\%o) (189). At the Von Damm vent field, higher concentrations of formate are found in hot mixed fluids than in pure end-member hydrothermal fluids, demonstrating that this species forms abiotically on timescales of hours to days (136). At Lost City, the $\delta^{13} \mathrm{C}$ of acetate $(-27 \%$ to $-17 \%$ ) could be attributed to a mixture of anaerobic fermentation and acetogenesis $(141,189)$. Given the high abundances of microorganisms in the chimneys, the acetate could also be due to a thermocatalytic breakdown of complex organics in the biomass $(141,189)$.

Hydrolyzable amino acids are present in high abundances in Lost City fluids and chimneys (142). In the fluids, the highest concentrations were observed in locations where concentrations of $\mathrm{H}_{2}$ had been drawn down by sulfate reducers living in the sub-seafloor or chimney. The ${ }^{13} \mathrm{C}$ of amino acids isolated from the chimneys had fractionation patterns consistent with synthesis by a chemolithoautotrophic source (142). In high-temperature fluids $\left(>300^{\circ} \mathrm{C}\right)$ from Rainbow and Ashadze, dissolved free amino acids were detected in the picomolar concentration range, with tryptophan, phenylalanine, and leucine detected in the fluids but not in deep seawater (180). Tryptophan and phenylalanine contain aromatic rings that may assist in molecular stability at high temperatures (190).

\subsubsection{Fluxes between the Ocean and Crust}

Hydrothermal circulation is the primary means of transferring materials between the crust and ocean $(78,191)$. The net flux of constituents includes both input and removal processes, though these may be geographically and temporally distinct. The impact of hydrothermal circulation on the carbon budget of the ocean remains unconstrained in many ways. 
Inorganic carbon is transferred to the deep ocean via magma degassing and removed by carbonate precipitation in the sub-seafloor at roughly similar rates (Figures 16.4 and 16.5). Degassing of mantle volatiles through high-temperature venting is estimated to input $\sim 1 \times$ $10^{12} \mathrm{~mol} \mathrm{C} \mathrm{yr}^{-1}$ of $\Sigma \mathrm{CO}_{2}$ into the ocean $(191,192)$. Carbonate precipitation is estimated to remove $1-3 \times 10^{12} \mathrm{~mol} \mathrm{C} \mathrm{yr}^{-1}$ in ridge flanks $(167,193,194)$. Seawater passing through peridotites results in a loss of $0.4-2.0 \times 10^{11} \mathrm{~mol} \mathrm{C} \mathrm{yr}^{-1}$, although stable isotope signatures indicate that approximately half of the carbon sequestered into the rock is in the form of organic carbon $(195,196)$.

Export and removal fluxes of DOC can be estimated by combining changes in concentrations with water fluxes through different types of hydrothermal systems $(75,80,163)$. If high-temperature vents remove an average of $20 \mu \mathrm{mol}$ of seawater DOC per liter, approximately $0.7-1.4 \times 10^{10} \mathrm{~g} \mathrm{C} \mathrm{yr}^{-1}$ would be lost globally (116). A similar scale loss of $1.4 \pm 0.7 \times 10^{10} \mathrm{~g} \mathrm{C} \mathrm{yr}^{-1}$ has been estimated based on changes of SPE-DOC concentrations (155). Ridge flank regions where crustal temperatures are "warm" $\left(>45^{\circ} \mathrm{C}\right)$ have more substantial chemical changes in circulating fluids but smaller fluid fluxes than regions where crustal temperatures are "cool" $(77,163)$. If concentrations from the "warm" Juan de Fuca ridge flank system are typical of such systems, 2-13 $\times 10^{10} \mathrm{~g} \mathrm{C} \mathrm{yr}^{-1}$ would be removed (116). Due to the larger water fluxes, if DOC concentrations through the "cool" crust at North Pond are globally representative, losses would be an order of magnitude higher at $\sim 9-14 \times 10^{11} \mathrm{~g} \mathrm{C} \mathrm{yr}^{-1}$ or $\sim 5 \%$ of the total annual deep oceanic DOC loss (135).

\subsection{Sedimented Hydrothermal Systems}

Where spreading centers occur under thick sediment packages, hot water rapidly alters the OM fueling heterotrophic communities (e.g. $(125,156,190))$, releasing inorganic carbon (89), influencing local physiochemical conditions, or forming complex oil-like materials (e.g. $(197,198)$ ). The form and fate of carbon in heated sediments depend on its origin (terrigenous versus marine versus chemoautotrophic), temperature, and flow rate. Upon heating, a series of reactions similar to those that give rise to petroleum proceeds, with important differences due to the more water-rich conditions. The production of petroleum is generally considered to begin at $\sim 50-70^{\circ} \mathrm{C}$ (199). Weak bonds that sorb organic molecules onto surfaces break most easily, followed by bonds involving oxygen, sulfur, or nitrogen. Carbon-carbon bonds require the most energy - and therefore greater temperature or time - to break (199).

Small polar compounds can be mobilized through enhanced desorption and the destruction of noncovalent bonds. The most labile material is removed from the solid phase due to microbial activity, pyrolysis, and/or desorption (156). Over time, the amount of OM transferred into the aqueous phase decreases as the material is physically transported out of the system or biodegraded by microorganisms $(125,156,157)$.

Unlike the dry "cracking" reactions that dominate petroleum reservoirs, breaking carboncarbon bonds in the presence of water results in more oxidized products. Cracking reactions proceed at temperatures above $\sim 100^{\circ} \mathrm{C}$ and result in $\mathrm{CH}_{4}$ and low-molecular-weight 
hydrocarbons (199-201). In contrast, in the presence of water and minerals, $n$-alkanes will instead degrade to oxygenated products such as alcohols, ketones, carboxylic acids, and, ultimately, $\mathrm{CO}_{2}$ and $\mathrm{CH}_{4}(89,202)$. Sediments heated in aqueous environments produce copious amounts of acetate in particular. The reaction temperature impacts the products, with higher temperatures favoring more oxidized products such as $\mathrm{CO}_{2}$ over $\mathrm{CH}_{4}$ and propanol over propane (203).

Reduction, condensation, and dehydration reactions proceed at higher temperatures to form macromolecules and aromatics, causing compounds to revert to their most stable states (Figure 16.4) (204,205). Polycyclic aromatic hydrocarbons and cyclic polysulfides, major components of some hydrothermal oils, form only under very high heat $\left(>\sim 300^{\circ} \mathrm{C}\right)$ and are signatures of elevated temperatures $(190,197,198)$. Polypeptides form through dehydration and reduction, while lipids crack and recombine (206).

Water washing will selectively transport more soluble components from the subsurface to the surface and leave behind larger condensates $(125,190,199,207)$. Smaller alkanes $\left(<\mathrm{C}_{10}\right)$, aromatic volatiles, compounds containing $\mathrm{C}-\mathrm{N}-\mathrm{S}$ bonds, oligosaccharides, and oligopeptides are often missing in sediments subjected to "water washing," while fluids and plumes contain higher concentrations of these compounds $(190,204,207)$.

These released compounds are highly biodegradable and fuel heterotrophic organisms. The labile amino acids released from sterilized sediments, for example, are utilized and reworked by microorganisms in parallel, nonsterilized experiments (125). In general, the low-molecular-weight organic acids that are primary breakdown products of heating sediments in the presence of water, particularly acetate, are important substrates for anaerobic microorganisms (208).

The residual OM that is not removed with water washing is enriched in less soluble material, leading to "hydrothermal petroleum." Cooling near the sediment-water interface can help trap less soluble compounds through differential condensation and solidification $(190,207,209)$. The distribution of compounds and the maturity of these oils are highly variable.

\subsection{Continental Subsurface}

Geological heterogeneity produced through plate tectonics diversifies and segments the continental deep subsurface and its constituent biospheres differently from in the marine realm. Mountain and basin formation juxtaposes reactive rocks and minerals and creates new hydrological flow paths. Rock and water ages on the continents range from modern to billions of years $(210,211)$. Terrestrial vegetation supplies vast quantities of organic carbon, although this influence is attenuated with increasing depth. The water age, hydrological connectivity, and major element chemistry of continental subsurface sites dramatically impact carbon cycling and the nature of in situ biospheres.

The continental deep subsurface extends downward from the base of the critical zone $(212,213)$, although specific depths and thresholds have yet to be defined, particularly on the upper boundary. The penetration of life into the continental crust appears to be 
limited not strictly by depth, but rather by temperature, permeability, and perhaps aridity, with clear life detection in even the deepest boreholes and mines. Sites lacking identifiable life are few and far between and appear to be limited by temperature (e.g. German continental deep drilling program (KTB) cores in the Black Forest (214)) or aridity (213).

Estimates of the size of the continental deep biosphere are large (ranging from $2.3 \times 10^{15}$ to $10^{17} \mathrm{~g} \mathrm{C}$ ), mirroring similar estimates of the marine deep biosphere $\left(4.1 \times 10^{15} \mathrm{~g} \mathrm{C}\right)$ and rivaling terrestrial soils $\left(2.6 \times 10^{16} \mathrm{~g} \mathrm{C}\right)(215-217)$. The uncertainty in these calculations spans orders of magnitude and has not changed significantly since the original estimates by Whitman (215; Chapter 17, this volume), although the trend is downward (Chapter 17, this volume). However, increasing levels of inquiry applied globally using advanced methodologies have identified abundant, taxonomically diverse communities within the continental deep subsurface, giving credence to vast amounts of carbon contained and being cycled by these ecosystems (218-222).

\subsubsection{Types of Continental Deep Subsurface Environments}

Continental deep subsurface environments can be broadly divided between sedimentary and crystalline host rocks, but even within this framework they range significantly in carbon content, isolation from the surface, and dominant carbon cycling processes (Figure 16.1). The best-studied sites are found in shallow sedimentary and igneous aquifers owing largely to their relevance to human water supplies (223-231). Hydrocarbon reservoirs contain vast quantities of organic carbon and have distinct microbiology associated with their formation waters (232-234). A recent emphasis on deep coal beds and their constituent carbon cycling has come to the scientific forefront due to their importance in gas extraction via deep fracking technologies (235). Deep crystalline bedrock sites feature the oldest, deepest, and most isolated deep biosphere environments (211,236-238). Caves, in contrast, sit at the interface between the surface and the deep and are covered more completely in other reviews (239-241). This section will describe the forms, cycling, and fate of organic carbon in each environment.

While the deep subsurface biosphere is pervasive, it is difficult to access reliably. Common access points are wells, boreholes, mines, and caves. Each approach has the potential to impact in situ processes and must be considered when evaluating data sets. Natural springs are often considered as "portals" or "windows" into the deep biosphere, often showing a mix of surface and subsurface communities $(242,243)$. The last 10 years has seen the establishment of a number of deep subsurface observatories including into permafrost (Permafrost Tunnel Research Facility, AL, USA), deep crystalline bedrock (Deep Mine Microbial Observatory (DeMMO), SD, USA; Coast Range Ophiolite Microbial Observatory (CrOMO), CA, USA; Äspö Hard Rock Laboratory, Sweden; and many others), and sedimentary aquifers (Deep Biosphere in Terrestrial Systems (DEBITS), New Zealand; Savannah River Site, SC, USA). 


\subsubsection{Continental Carbon Cycling}

Organic carbon in the continental deep biosphere may derive from surficial inputs, in situ autotrophic carbon fixation, water-rock reactions, or ancient sedimentary sources. The relative balance of these sources depends sharply on geology, both by surface connectivity and host lithology. The following sections describe this balance in sedimentary and igneous aquifers, hydrocarbon reservoirs, deep coal beds, and deep crystalline bedrock.

Key processes in subsurface carbon cycling depend on the relative recalcitrance of ancient OM, supply of labile organic carbon, input of metabolic oxidants and reductants, and aquifer porosity and permeability. Microbial carbon fixation produces labile organic carbon and methane, whereas heterotrophic microbial processes consume both labile and recalcitrant subsurface organic carbon. The relative importance of these two end members broadly suggests autotrophic processes dominate in crystalline and deep rock aquifers whereas heterotrophic processes are more abundant within sedimentary systems, although numerous counterexamples exist and both processes (e.g. (251)) must be active for a functioning ecosystem (225). Organic acids and short-chain hydrocarbons are key microbial products and substrates within most continental subsurface settings with typical concentrations in the 10-100 $\mu \mathrm{M}$ range (Table 16.2). Due to rock dissolution and other processes, DIC can be very high, and may get much higher as aquifers are targeted for anthropogenic carbon sequestration (222).

\subsubsection{Sedimentary and Igneous Aquifers}

Both sedimentary (e.g. Atlantic coastal plain) and igneous aquifers (e.g. Columbia River basalt aquifer) have been shown to contain vibrant microbial communities and have been the subject of intensive study due to their economic and social importance as sources of drinking and industrial water, as well as their vulnerability to anthropogenic contamination $(225,226,231)$. Recharge timescales of aquifers vary over many orders of magnitude (months to millions of years), controlling the relative supply of exogenous DOC and electron acceptors. In many systems, significant supply of young sedimentary carbon produces relatively high DOC, methane, and organic acid concentrations. The composition of this DOC can be complex, including significant amounts of nitrogen- and sulfur-bearing organic molecules (252). While oligotrophic compared to surface environments, aquifers are relatively carbon rich for the subsurface and can support correspondingly high cell densities (e.g. $10^{5}$ cells $/ \mathrm{mL}$ ), even in oligotrophic crystalline aquifers (246).

Primary productivity within aquifers varies tremendously based on exogenous and sedimentary organic carbon supply, but is significant in some settings. Hydrogen production can be large and may support autotrophic populations, particularly in igneous and ultrabasic host environments, fueling the so-called subsurface lithoautotrophic microbial ecosystems $(223,251,253)$. Utilization of iron oxide minerals as terminal electron acceptors for both autotrophic and heterotrophic metabolisms is common, producing high concentrations of dissolved ferrous iron in many groundwaters 


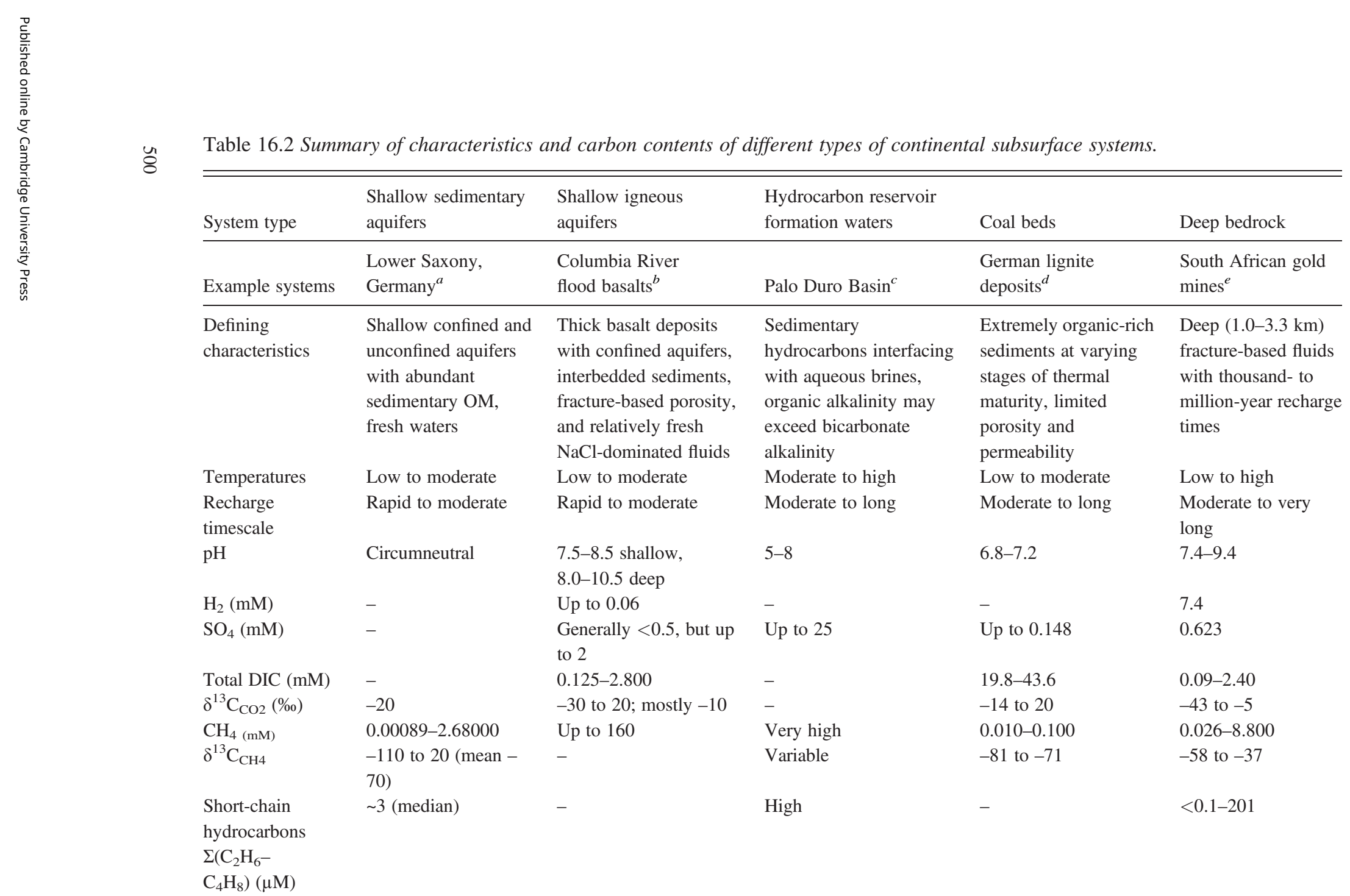




\begin{tabular}{llllll} 
DOC $(\mathrm{mM})$ & $0.17-0.30$ & $0.16-0.39$ & $0.05-14.75$ & $0.19-0.95$ & n.d. to 0.410 \\
Formate & - & - & - & $2.22-31.1 \mu \mathrm{mol} / \mathrm{g}$ sed & $0.44-34.00 \mu \mathrm{M}$ \\
Acetate & - & - & $6.08 \mathrm{mM}$ & $1.7-8.5 \mu \mathrm{mol} / \mathrm{g} \mathrm{sed}$ & $0.07-28.00 \mu \mathrm{M}$ \\
Amino acids & - & - & - & - & $0.0133-2.6700 \mu \mathrm{M}$ \\
Typical cell & $10^{3}-10^{8}$ & $10^{3}-10^{5}$ & High & $10^{7}$ & $10-10^{5}$ \\
density $($ cells $/ \mathrm{mL})$ & & & & \\
\hline \hline
\end{tabular}

Ranges are reported for the example systems, where there are data available. Ranges and qualitative measures are given where there is significant variability reported or differences between reports. "-” is used to indicate no available reports.

sed $=$ sediment.

${ }^{a}(229,244,245)$.

${ }^{b}(223,246)$.

${ }^{c}(228,232,233)$.

$d(228,247)$.

e $(248-250)$.

${ }^{f}$ Aqueous extracts. 
$(254,255)$. Iron and sulfur oxidative metabolisms are also found where microaerophilic conditions or sufficient nitrate concentrations exist $(254,256)$. Sulfate is a less dominant anion in continental settings relative to its ubiquity in the marine realm, but where present, it can fuel significant populations of autotrophic and heterotrophic sulfatereducing bacteria $(254,255)$.

Heterotrophic processes rely on the input of DOC from the mineralization of sedimentary carbon, aquifer recharge, or in situ microbial activity. In $85 \%$ of US aquifers, DOC concentrations were $<175 \mu \mathrm{M}$ (median 42 and $58 \mu \mathrm{M}$ ). These ranges were not significantly different between sedimentary and crystalline aquifers (ranging from 8 to $275 \mu \mathrm{M}$, median $42 \mu \mathrm{M})(257)$. A more recent analysis of DOC concentration across UK aquifers showed a range of $15-1550 \mu \mathrm{M}(257 \mu \mathrm{M}$ average) (226), although this sampling includes evidence for significant contamination from agriculture and concomitant microbial respiration that introduced OM. Locally, high concentrations of organic acids (up to $60 \mu \mathrm{M}$ formate) can be produced by microbial degradation of complex sedimentary OM, particular in shale horizons, which may then diffuse to more porous sediments, driving respiration (258). For shallow aquifer systems, periodic environmental changes related to seasonal shifts, water table fluctuations, or land use may transport both DOC and oxidants to depth, driving increases in heterotrophic respiration (244,259).

Methane is a ubiquitous reservoir of organic carbon in sedimentary aquifers. Methane concentrations are extremely variable but sometimes can reach extremely high values (e.g. $0.9 \mathrm{nM}$ to $2.7 \mathrm{mM}$ in the Lower Saxony region of Germany (229) and $3.1 \mathrm{nM}$ to $293 \mu \mathrm{M}$ across Great Britain (230)). Sources of methane vary and include abiotic and biotic sources, including microbial methanogenesis (including hydrogenotrophic, acetoclastic, and methyl fermentation) as well as thermogenic cracking of buried OM $(224,229,230)$. The isotopic composition of methane and co-occurring short-chain hydrocarbons can be used to assess methane sources and suggest active microbial $\mathrm{CO}_{2}$ reduction as the primary source in both German and British aquifers $(229,230)$. High concentrations tend to correlate to organic-rich, low- $\mathrm{SO}_{4}$ geological formations (229).

\subsubsection{Hydrocarbon Reservoirs}

Hydrocarbon reservoirs were among the earliest studied continental deep biospheres, with experiments beginning in the 1920 s by Colwell and D'Hondt (213). These systems are characterized by large accumulations of liquid and gaseous hydrocarbons, providing abundant sources of carbon and electron donors, but they tend to be correspondingly depleted in oxidants and nutrients. Extremely high concentrations of volatile organic acids (particularly acetate) comprise the majority of DOC in the water phases of hydrocarbonbearing basins, reaching concentrations of up to hundreds of $\mathrm{mM}(232,260,261)$.

The most significant metabolisms in hydrocarbon reservoirs are sulfate reduction, methanogenesis, acetogenesis, iron reduction, and fermentation (260-262), the balance of which is determined by electron acceptor supply. Spatially, biodegradation of oil is concentrated at the oil-water interface and is limited by reservoir temperature, with limited 
activity being observed above $80^{\circ} \mathrm{C}(234,263)$. Anthropogenic influence through drilling, water introduction, casing, and fracturing of reservoirs and the introduction of exogenous microbes can significantly change in situ carbon cycling, most notoriously causing reservoir souring by stimulating sulfate-reducing populations in previously methanogenic reservoirs. For more a complete description of carbon cycling and biodegradation in hydrocarbon reservoirs, see the reviews by Larter et al. (263), Means and Hubbard (232), and Head et al. (260).

\subsubsection{Deep Coal Beds}

Coal is formed through the burial and diagenesis of large accumulations of terrestrial plant matter and therefore contains an extremely high organic carbon content. The bioavailablity of this OM to deep subsurface microbes depends on thermal maturity and burial history, which control the form and speciation of $\mathrm{OM}$ as well as the sterilization history of resident microbial populations (235). Low-maturity (rank) coals are the most bioavailable and actively accumulate biogenic methane. Aqueous extracts of low-maturity coals and lignites produce extremely high concentrations of organic acids, including acetate, formate, and oxalate in the range of $0.37-2.5 .0 \mathrm{mg} / \mathrm{g}$ sediment $(247,264)$. Yields of labile OM decrease significantly with increasing thermal maturity $(247,264)$.

Biogenic methane appears to universally accumulate in coals at $<80^{\circ} \mathrm{C}$ (235). Microbial processing of coal to methane is a multistep process that requires and supports an ecosystem of microbes. First, organic polymers are fragmented into hydrocarbon intermediates, followed by a secondary fermentation to methanogenic substrates like $\mathrm{CO}_{2}, \mathrm{H}_{2}$, organic acids, and alcohols. These substrates then fuel acetoclastic, methylotrophic, and hydrogenotrophic methanogens (235). The rate and efficiency of these processes in different coal deposits and the accessibility of this methane for extraction are of considerable economic importance. For a more complete review of coal bed biogeochemistry, see Strapoc et al. (235).

\subsubsection{Deep Bedrock}

Deep crystalline bedrock-hosted biospheres stand in contrast to the aforementioned settings in their constituent reservoirs and fluxes of carbon and energy. Here, inputs from the surface are limited, with water residence times reaching millions to billions of years (e.g. $(211,265)$ ) and sedimentary carbon (where present) is recalcitrant to graphitic carbon (266). The largest pool of organic carbon is often as methane, although considerable variability is present with depth and lithology $(248,266)$. Porosity and permeability is fracture based, adding a stochastic temporal dynamic to fluxes and mixing $(265,267)$.

Hydrogen, methane, sulfate, and iron cycling drive primary production in deep crystalline bedrock settings. The relative importance of these processes is variable with depth, host lithology, and fluid chemistry $(221,248)$. Precambrian rocks, which constitute the 
best-studied deep crystalline biospheres, are prolific producers of hydrogen (up to $\mathrm{mM}$ concentrations) $(238,267)$, which can serve as the terminal electron donor for either sulfate reduction or $\mathrm{CO}_{2}$ reduction-based metabolisms (249,265,268-272).

Analysis of subsurface genomes shows that enzymes of hydrogen metabolism are overrepresented, emphasizing the potential dominance of this metabolic strategy (273). Metagenomic surveys suggest that carbon fixation is performed primarily using the reductive acetyl CoA pathway $(256,271,272)$. Extreme metabolic flexibility has been observed in the cosmopolitan subsurface dweller Candidatus Desulforudis audaxviator, which can grow in near monoculture in isolated fracture systems (220) and has been found globally $(221,274)$.

Heterotrophic microbes and metabolisms have been found to dominate in some deep crystalline settings, despite the apparent limited availability of exogenous carbon. Abiogenic sources of methane in addition to limited populations of microbial methanogens supply a significant flux of methane to fuel methanotrophic communities reaching tens of $\mathrm{mM}$ concentrations $(248,266,275,276)$. Methane cycling has been observed to be most active at moderate depths $(0.5-1.5 \mathrm{~km})$ rather than in the deepest, most isolated settings $(248,266,277)$. Other sources of carbon for heterotrophic communities include biofilmbased small organic compounds $(265,278)$, free organic acids formed through fermentation or abiogenesis, and ancient organic carbon (279).

Mineral and biofilm-based metabolisms may be particularly important in deep crystalline settings. Increasing evidence of extensive adaptation to life in biofilms is emerging from these environments in the form of physical adaptations like grappling appendages observed in putative Candidatus "Altiarchaeum" (256), as well extracellular electron transport in subsurface isolates (280). In high-pH settings, autotrophic populations may depend on solid carbonate minerals due to carbon speciation in ultrabasic environments (269). Differences between the attached and planktonic communities have long been observed in crystalline aquifer settings $(221,277,281)$, often with orders of magnitude higher cell densities present within the biofilms (278). The net suggestion of these observations is that mineral and biofilm-based lifestyles are the norm for the deep continental subsurface, but are as yet undersampled. Efforts to cultivate and characterize the metabolic capacities of these attached communities are underway.

\subsection{Conclusion}

\subsubsection{Broad Similarities across Systems}

The deep biosphere spans an incredible range of physical and chemical conditions. Despite their heterogeneity, some broad similarities are present across systems. Organic carbon concentrations reach their highest levels in regions that have large inputs from primary producers, either presently (continental margins, shallow sedimentary aquifers, diffuse hydrothermal vents) or in the past (hydrocarbon reservoirs, coal beds). In contrast, concentrations are lower in rocky areas with little sedimentary input and low amounts of 
chemolithoautotrophy in both continental (shallow igneous aquifers, deep bedrock) and marine (ridge flanks, high-temperature hydrothermal vents) systems. Elevated concentrations of methane are related to the anaerobic breakdown of $\mathrm{OM}$ and associated methanogenesis (sedimentary porewaters, sedimented hydrothermal systems, hydrocarbon reservoirs, coal beds), but also due to hydrogenotrophic methanogenesis, with the hydrogen supplied by water-rock reactions (basalts) and from mantle inputs (hydrothermal systems). Somewhat surprising is the persistence of some forms of organic carbon that are generally thought to be readily accessible to microorganisms, such as acetate, in many systems (sedimentary porewaters, shallow igneous aquifers, deep bedrock).

\subsubsection{Limits to Knowledge and Unknowns}

(1) Exchange/transformation of carbon between aqueous and solid phases. A characteristic of subsurface environments is the ubiquitous presence of a solid phase, be it from surface-derived particles or crystalline rocks. The exchange and transformation of carbon between the aqueous and solid phases is therefore a major mechanism for controlling the form and fate of carbon in the subsurface. Major questions remain as to what controls these exchanges and the degree to which they are catalyzed by minerals and microorganisms.

(2) Bioavailability of organic carbon. Microbial respiration has been invoked to account for the oxidation of OM that is millions of years old in sediments (67) and the removal of oceanic dissolved OM that is thousands of years old in the basaltic basement (135). Even 365 million-year-old shale carbon can be incorporated into cellular biomass given the right conditions (282). These studies raise the intriguing question of whether all $\mathrm{OM}$ is, ultimately, bioavailable give enough time and a favorable setting, or whether there is some pool that will resist remineralization to $\mathrm{CO}_{2}$ under all circumstances. This question ties directly into point (3) below.

(3) Controls on reaction rates of biogeochemical processes. The rate at which carbon is transformed or remineralized is fundamentally important to understanding the short- and long-term controls on the global carbon cycle and to identifying the distribution of subsurface life. The processes occurring in the marine and continental subsurface are inherently difficult to accurately mimic in laboratory experiments. While short-term experiments can address the more reactive portions of the organic pool, our understanding of the transformations that occur over century or millennium timescales, particularly when uncultured microorganisms mediate the reactions, is more challenging but no less important.

(4) Predictive ability. This review describes what types of carbon are present in distinct geological, geochemical, and biological environments. Ultimately, however, the reverse is a major goal: the ability to have such a fundamental grasp of the mechanistic controls on carbon cycling that it is possible to accurately predict what types and abundances of carbon will be present in a given system. 
(5) Characterization of OM. Despite decades of effort and major progress on several fronts, the molecular structure of the vast majority of $\mathrm{OM}$ in the subsurface remains uncharacterized. This gap in our knowledge will continue to inhibit our understanding of carbon biogeochemical cycling in the subsurface.

\section{Acknowledgments}

Funding support for SQL is from C-DEBI (NSF grant OIA-0939564) and National Science Foundation grant OCE-1536702. Funding support for ADS is from C-DEBI and NSF OCE-1357242. Funding support for MRO is from NASA Exobiology (NNH14ZDA001N) and NAI Life Underground (NNH12ZDA002C). This is C-DEBI contribution 475.

\section{Questions for the Classroom}

1 Continental and oceanic subsurface crystalline aquifers are similar in many ways. How do the characteristics of carbon in, for example, the oceanic North Pond and the continental South African gold mine systems compare and differ? Why?

2 Are the sites studied thus far representative of globally relevant locations where carbon is processed in the subsurface? What locations or geological systems are missing? Why have these not yet been studied? What are the prospects for studying these locations?

3 What effect are humans having on carbon in the deep biosphere?

4 What are the next steps to improve our ability to computationally model different forms of carbon in the subsurface and how they change in the subsurface?

5 Imagine a hypothetical microorganism that is capable of remineralizing any type of nonbioavailable $\mathrm{OM}$ back to $\mathrm{CO}_{2}$. If this microorganism proliferated in subsurface environments, what would the effect be?

6 Ultraviolet radiation can create radical species (compounds that are highly reactive due to the presence of an unpaired electron) that can oxidize organic molecules via random reactions. What is the likely effect of a change in atmospheric ozone concentrations, and therefore ultraviolet flux to Earth's surface, on organic carbon burial rates?

\section{References}

1. Martiny JBH, Bohannan BJM, Brown JH, Colwell RK, Fuhrman JA, Green JL, et al. Microbial biogeography: putting microorganisms on the map. Nature Reviews Microbiology. 2006;4(2):102-112.

2. Hedges JI. Global biogeochemical cycles - progress and problems. Marine Chemistry. 1992;39(1-3):67-93. 
3. Schrenk M, Huber J, Edwards K. Microbial provinces in the subseafloor. Annual Review of Marine Science. 2010;2:279-304.

4. Rex MA, Etter RJ, Morris JS, Crouse J, McClain CR, Johnson NA, et al. Global bathymetric patterns of standing stock and body size in the deep-sea benthos. Marine Ecology Progress Series. 2006;317:1-8.

5. LaRowe DE, Burwicz E, Arndt S, Dale AW, Amend JP. Temperature and volume of global marine sediments. Geology. 2017;45(3):275-278.

6. Burdige DJ. Burial of terrestrial organic matter in marine sediments: a re-assessment. Global Biogeochemical Cycles. 2005;19(4):GB4011.

7. Burdige DJ. Preservation of organic matter in marine sediments: controls, mechanisms, and an imbalance in sediment organic carbon budgets? Chemical Reviews. 2007;107(2):467-485.

8. Hedges JI, Keil RG. Sedimentary organic matter preservation - an assessment and speculative synthesis. Marine Chemistry. 1995;49(2-3):81-115.

9. Zonneveld KAF, Versteegh GJM, Kasten S, Eglinton TI, Emeis KC, Huguet C, et al. Selective preservation of organic matter in marine environments; processes and impact on the sedimentary record. Biogeosciences. 2010;7(2):483-511.

10. Blair NE, Aller RC. The fate of terrestrial organic carbon in the marine environment. Annual Review of Marine Science. 2012;4:401-423.

11. Keil RG, Mayer LM. Mineral matrices and organic matter. In: Holland HD, Turekian KK, eds. Treatise on Geochemistry, 2nd edn. Oxford: Elsevier, 2014, pp. 337-359.

12. Keil R, Annual R. Anthropogenic forcing of carbonate and organic carbon preservation in marine sediments. Annual Review of Marine Sciences, 2017;9:151-172.

13. Middelburg JJ. Reviews and syntheses: to the bottom of carbon processing at the seafloor. Biogeosciences. 2018;15(2):413-427.

14. Hedges JI, Keil RG, Benner R. What happens to terrestrial organic matter in the ocean? Organic Geochemistry. 1997;27(5-6):195-212.

15. Blair NE, Leithold EL, Ford ST, Peeler KA, Holmes JC, Perkey DW. The persistence of memory: the fate of ancient sedimentary organic carbon in a modern sedimentary system. Geochimica et Cosmochimica Acta. 2003;67(1):63-73.

16. Galy V, Peucker-Ehrenbrink B, Eglinton T. Global carbon export from the terrestrial biosphere controlled by erosion. Nature. 2015;521(7551):204-207.

17. Hilton RG, Galy A, Hovius N, Horng MJ, Chen H. Efficient transport of fossil organic carbon to the ocean by steep mountain rivers: an orogenic carbon sequestration mechanism. Geology. 2011;39(1):71-74.

18. Goni MA, Hatten JA, Wheatcroft RA, Borgeld JC. Particulate organic matter export by two contrasting small mountainous rivers from the Pacific Northwest, USA. Journal of Geophysical Research - Biogeosciences. 2013;118(1):112-134.

19. Bao HY, Lee TY, Huang JC, Feng XJ, Dai MH, Kao SJ. Importance of Oceanian small mountainous rivers (SMRs) in global land-to-ocean output of lignin and modern biospheric carbon. Scientific Reports. 2015;5:16217.

20. Opsahl S, Benner R, Amon RMW. Major flux of terrigenous dissolved organic matter through the Arctic Ocean. Limnology and Oceanography. 1999;44(8): 2017-2023.

21. Dittmar T, Kattner G. The biogeochemistry of the river and shelf ecosystem of the Arctic Ocean: a review. Marine Chemistry. 2003;83(3-4):103-120.

22. Raymond PA, McClelland JW, Holmes RM, Zhulidov AV, Mull K, Peterson BJ, et al. Flux and age of dissolved organic carbon exported to the Arctic Ocean: a carbon 
isotopic study of the five largest arctic rivers. Global Biogeochemical Cycles. 2007;21(4):GB4011.

23. Feng XJ, Vonk JE, van Dongen BE, Gustafsson O, Semiletov IP, Dudarev OV, et al. Differential mobilization of terrestrial carbon pools in Eurasian Arctic river basins. Proceedings of the National Academy of Sciences of the United States of America. 2013;110(35):14168-14173.

24. Blair NE, Carter WD, Boehme SE. Diagenetic isotope effects in an anoxic marine sediment. Abstracts of Papers of the American Chemical Society. 1991;201:34GEOC.

25. Schmitz RA, Daniel R, Deppenmeier U, Gottschalk G. The Anaerobic Way of Life. Prokaryotes: A Handbook on the Biology of Bacteria, Vol. 2, 3rd edn: Ecophysiology and Biochemistry. Washington, DC: American Chemical Society, 2006, pp. 86-101.

26. Blair NE, Martens CS, Desmarais DJ. Natural abundances of carbon isotopes in acetate from a coastal marine sediment. Science. 1987;236(4797):66-68.

27. Gelwicks JT, Risatti JB, Hayes JM. Carbon isotope effects associated with aceticlastic methanogenesis. Applied and Environmental Microbiology. 1994;60(2):467-472.

28. Hinrichs KU, Hayes JM, Bach W, Spivack AJ, Hmelo LR, Holm NG, et al. Biological formation of ethane and propane in the deep marine subsurface. Proceedings of the National Academy of Sciences of the United States of America. 2006;103 (40):14684-14689.

29. Heuer VB, Pohlman JW, Torres ME, Elvert M, Hinrichs KU. The stable carbon isotope biogeochemistry of acetate and other dissolved carbon species in deep subseafloor sediments at the northern Cascadia Margin. Geochimica et Cosmochimica Acta. 2009;73(11):3323-3336.

30. Suess E. Particulate organic-carbon flux in the oceans - surface productivity and oxygen utilization. Nature. 1980;288(5788):260-263.

31. Abdulla H, Burdige D, Komada T. Accumulation of deaminated peptides in anoxic sediments of Santa Barbara Basin. Geochimica et Cosmochimica Acta. 2018;223: $245-258$.

32. Jiao N, Herndl G, Hansell D, Benner R, Kattner G, Wilhelm S, et al. Microbial production of recalcitrant dissolved organic matter: long-term carbon storage in the global ocean. Nature Reviews Microbiology. 2010;8(8):593-599.

33. Lechtenfeld OJ, Kattner G, Flerus R, McCallister SL, Schmitt-Kopplin P, Koch BP. Molecular transformation and degradation of refractory dissolved organic matter in the Atlantic and Southern Ocean. Geochimica et Cosmochimica Acta. 2014;126: 321-337.

34. Hartnett HE, Keil RG, Hedges JI, Devol AH. Influence of oxygen exposure time on organic carbon preservation in continental margin sediments. Nature. 1998;391 (6667):572-574.

35. Hee CA, Pease TK, Alperin MJ, Martens CS. Dissolved organic carbon production and consumption in anoxic marine sediments: a pulsed-tracer experiment. Limnology and Oceanography. 2001;46(8):1908-1920.

36. Benz R, Bauer K. Permeation of hydrophilic molecules through the outer membrane of Gram-negative bacteria. European Journal of Biochemistry. 1988;176:1-19.

37. Burdige DJ, Gardner KG. Molecular weight distribution of dissolved organic carbon in marine sediment pore waters. Marine Chemistry. 1998;62(1-2):45-64.

38. Simpson AJ, Kingery WL, Hayes MHB, Spraul M, Humpfer E, Dvortsak P, et al. Molecular structures and associations of humic substances in the terrestrial environment. Naturwissenschaften. 2002;89(2):84-88. 
39. Benner R, Amon RMW. The size-reactivity continuum of major bioelements in the ocean. Annual Review of Marine Science. 2015;7:185-205.

40. Walker BD, Beaupre SR, Guilderson TP, McCarthy MD, Druffel ERM. Pacific carbon cycling constrained by organic matter size, age and composition relationships. Nature Geoscience. 2016;9(12):888-891.

41. Kelleher BP, Simpson AJ. Humic substances in soils: are they really chemically distinct? Environmental Science \& Technology. 2006;40(15):4605-4611.

42. Coolen MJL, Overmann J. Functional exoenzymes as indicators of metabolically active bacteria in 124,000-year-old sapropel layers of the eastern Mediterranean Sea. Applied and Environmental Microbiology. 2000;66(6):2589-2598.

43. Coolen MJL, Cypionka H, Sass AM, Sass H, Overmann J. Ongoing modification of Mediterranean Pleistocene sapropels mediated by prokaryotes. Science. 2002;296 (5577):2407-2410.

44. Schmidt JM. Microbial Extracellular Enzymes in Marine Sediments: Methods Development and Potential Activities in the Baltic Sea Deep Biosphere. Masters thesis, University of Tennessee, 2016.

45. Robador A, Bruchert V, Steen AD, Arnosti C. Temperature induced decoupling of enzymatic hydrolysis and carbon remineralization in long-term incubations of Arctic and temperate sediments. Geochimica et Cosmochimica Acta. 2010;74(8):2316-2326.

46. Noinaj N, Guillier M, Barnard TJ, Buchanan SK. TonB-dependent transporters: regulation, structure, and function. Annual Review of Microbiology. 2010;64:43-60.

47. Arnosti C, Repeta DJ. Extracellular enzyme activity in anaerobic bacterial cultures evidence of pullulanase activity among mesophilic marine bacteria. Applied and Environmental Microbiology. 1994;60(3):840-846.

48. Cuskin F, Lowe EC, Temple MJ, Zhu YP, Cameron EA, Pudlo NA, et al. Human gut Bacteroidetes can utilize yeast mannan through a selfish mechanism. Nature. 2015;517(7533):165-186.

49. Tanoue E, Handa N. Distribution of particulate organic carbon and nitrogen in the Bering Sea and Northern North Pacific Ocean. Journal of the Oceanographical Society of Japan. 1979;35:47-62.

50. Mayer LM. Relationships between mineral surfaces and organic carbon concentrations in soils and sediments. Chemical Geology. 1994;114(3-4):347-363.

51. Mayer LM. Surface area control of organic carbon accumulation in continental shelf sediments. Geochimica et Cosmochimica Acta. 1994;58(4):1271-1284.

52. Mayer LM. Extent of coverage of mineral surfaces by organic matter in marine sediments. Geochimica et Cosmochimica Acta. 1999;63(2):207-215.

53. Knicker H, Hatcher PG. Survival of protein in an organic-rich sediment: possible protection by encapsulation in organic matter. Naturwissenschaften. 1997;84(6): 231-234.

54. Moore EK, Nunn BL, Goodlett DR, Harvey HR. Identifying and tracking proteins through the marine water column: insights into the inputs and preservation mechanisms of protein in sediments. Geochimica et Cosmochimica Acta. 2012;83: 324-359.

55. Wu SC, Gschwend PM. Sorption kinetics of hydrophobic organic compounds to natural sediments and soils. Environmental Science \& Technology. 1986;20(7): 717-725.

56. Espeland E, Wetzel R. Complexation, stabilization, and UV photolysis of extracellular and surface-bound glucosidase and alkaline phosphatase: implications for biofilm microbiota. Microbial Ecology. 2001;42(4):572-585. 
57. Tietjen T, Wetzel R. Extracellular enzyme-clay mineral complexes: enzyme adsorption, alteration of enzyme activity, and protection from photodegradation. Aquatic Ecology. 2003;37(4):331-339.

58. Lalonde K, Mucci A, Ouellet A, Gelinas Y. Preservation of organic matter in sediments promoted by iron. Nature. 2012;483(7388):198-200.

59. Barber A, Brandes J, Leri A, Lalonde K, Balind K, Wirick S, et al. Preservation of organic matter in marine sediments by inner-sphere interactions with reactive iron. Scientific Reports. 2017;7:366.

60. Cowie GL, Hedges JI. The role of anoxia in organic matter preservation in coastal sediments - relative stabilities of the major biochemicals under oxic and anoxic depositional conditions. Organic Geochemistry. 1992;19(1-3):229-234.

61. Canfield DE. Factors influencing organic carbon preservation in marine sediments. Chemical Geology. 1994;114(3-4):315-329.

62. Keil RG, Hu FS, Tsamakis EC, Hedges JI. Pollen in marine sediments as an indicator of oxidation of organic matter. Nature. 1994;369(6482):639-641.

63. Hedges JI, Hu FS, Devol AH, Hartnett HE, Tsamakis E, Keil RG. Sedimentary organic matter preservation: a test for selective degradation under oxic conditions. American Journal of Science. 1999;299(7-9):529-555.

64. Kirk TK, Farrell RL. Enzymatic combustion - the microbial-degradation of lignin. Annual Review of Microbiology. 1987;41:465-505.

65. Cowie GL, Hedges JI, Prahl FG, Delange GJ. Elemental and major biochemical changes across an oxidation front in an relict turbidite - an oxygen effect. Geochimica et Cosmochimica Acta. 1995;59(1):33-46.

66. Cowie GL, Calvert SE, Pedersen TF, Schulz H, von Rad U. Organic content and preservational controls in surficial shelf and slope sediments from the Arabian Sea (Pakistan margin). Marine Geology. 1999;161(1):23-38.

67. Røy H, et al. Aerobic microbial respiration in 86-million-year-old deep sea red clay. Science. 2012;336:922-925.

68. Westrich JT, Berner RA. The role of sedimentary organic matter in bacterial sulfate reduction - the G model tested. Limnology and Oceanography. 1984;29(2): 236-249.

69. Boudreau BP, Ruddick BR. On a reactive continuum representation of organicmatter diagenesis. American Journal of Science. 1991;291(5):507-538.

70. Tarutis WJ. On the equivalence of the power and reactive continuum models of organic-matter diagenesis. Geochimica et Cosmochimica Acta. 1993;57(6):1349-1350.

71. Middelburg JJ. A simple rate model for organic matter decomposition in marine sediments. Geochimica et Cosmochimica Acta. 1989;53(7):1577-1581.

72. Hedges JI, Eglinton G, Hatcher PG, Kirchman DL, Arnosti C, Derenne S, et al. The molecularly-uncharacterized component of nonliving organic matter in natural environments. Organic Geochemistry. 2000;31(10):945-958.

73. Wieder WR, Bonan GB, Allison SD. Global soil carbon projections are improved by modelling microbial processes. Nature Climate Change. 2013;3(10):909-912.

74. Bradley JA, Amend JP, LaRowe DE. Bioenergetic controls on microbial ecophysiology in marine sediments. Frontiers in Microbiology. 2018;9:180.

75. Johnson HP, Pruis MJ. Fluxes of fluid and heat from the oceanic crustal reservoir. Earth and Planetary Science Letters. 2003;216(4):565-574.

76. Edmond JM, Measures C, McDuff RE, Chan LH, Collier R, Grant B, et al. Ridge crest hydrothermal activity and the balances of the major and minor elements in the ocean - Galapagos data. Earth and Planetary Science Letters. 1979;46(1):1-18. 
77. Mottl MJ, Wheat CG. Hydrothermal circulation through midocean ridge flanks fluxes of heat and magnesium. Geochimica et Cosmochimica Acta. 1994;58 (10):2225-2237.

78. Elderfield H, Schultz A. Mid-ocean ridge hydrothermal fluxes and the chemical composition of the ocean. Annual Review of Earth and Planetary Sciences. 1996;24:191-224.

79. German CR, Casciotti KA, Dutay JC, Heimburger LE, Jenkins WJ, Measures CI, et al. Hydrothermal impacts on trace element and isotope ocean biogeochemistry. Philosophical Transactions of the Royal Society A -Mathematical Physical and Engineering Sciences. 2016;374(2081):20160035.

80. Stein CA, Stein S. Constraints on hydrothermal heat-flux through the oceanic lithosphere from global heat flow. Journal of Geophysical Research - Solid Earth. 1994;99(B2):3081-3095.

81. Alt JC. Sulfur isotopic profile through the oceanic-crust - sulfur mobility and seawater-crustal sulfur exchange during hydrothermal alteration. Geology. 1995;23 (7):585-588.

82. Summit M, Baross JA. A novel microbial habitat in the mid-ocean ridge subseafloor. Proceedings of the National Academy of Sciences of the United States of America. 2001;98(5):2158-2163.

83. Santelli CM, Orcutt BN, Banning E, Bach W, Moyer CL, Sogin ML, et al. Abundance and diversity of microbial life in ocean crust. Nature. 2008;453(7195): 653-657.

84. Orcutt BN, Sylvan JB, Knab NJ, Edwards KJ. Microbial ecology of the dark ocean above, at, and below the seafloor. Microbiology and Molecular Biology Reviews. 2011;75(2):361-422.

85. Sclater JG, Jaupart C, Galson D. The heat flow through oceanic and continental crust and the heat loss of the Earth. Reviews of Geophysics. 1980;18(1):269-311.

86. Butterfield DA, McDuff RE, Mottl MJ, Lilley MD, Lupton JE, Massoth GJ. Gradients in the composition of hydrothermal fluids from the Endeavor Segment vent field - phase-separation and brine loss. Journal of Geophysical Research - Solid Earth. 1994;99(B5):9561-9583.

87. Tivey MK, Bradley AM, Joyce TM, Kadko D. Insights into tide-related variability at seafloor hydrothermal vents from time-series temperature measurements. Earth and Planetary Science Letters. 2002;202(3-4):693-707.

88. Lilley MD, Butterfield DA, Lupton JE, Olson EJ. Magmatic events can produce rapid changes in hydrothermal vent chemistry. Nature. 2003;422(6934):878-881.

89. Seewald J, Cruse A, Saccocia P. Aqueous volatiles in hydrothermal fluids from the Main Endeavour Field, northern Juan de Fuca Ridge: temporal variability following earthquake activity. Earth and Planetary Science Letters. 2003;216 (4):575-590.

90. Sarmiento JL, Gruber N. Ocean Biogeochemical Dynamics. Princeton, NJ: Princeton University Press, 2006.

91. Hansell DA, Carlson CA, Repeta DJ, Schlitzer R. Dissolved organic matter in the ocean a controversy stimulates new insights. Oceanography. 2009;22(4):202-211.

92. Hansell DA. Recalcitrant dissolved organic carbon fractions. Annual Review of Marine Science. 2013;5:421-445.

93. Druffel ERM, Williams PM, Bauer JE, Ertel Jr. Cycling of dissolved and particulate organic-matter in the open ocean. Journal of Geophysical Research - Oceans. 1992;97(C10):15639-15659. 
94. Hertkorn N, Benner R, Frommberger M, Schmitt-Kopplin P, Witt M, Kaiser K, et al. Characterization of a major refractory component of marine dissolved organic matter. Geochimica et Cosmochimica Acta. 2006;70(12):2990-3010.

95. Aluwihare LI, Repeta DJ, Chen RF. A major biopolymeric component to dissolved organic carbon in surface sea water. Nature. 1997;387(6629):166-169.

96. Arakawa N, Aluwihare LI, Simpson AJ, Soong R, Stephens BM, Lane-Coplen D. Carotenoids are the likely precursor of a significant fraction of marine dissolved organic matter. Science Advances. 2017;3(9):e1602976.

97. Repeta DJ. Chemical characterization and cycling of dissolved organic matter. In: Hansell D, ed. Biogeochemistry of Marine Dissolved Organic Matter. Washington, DC: American Association for the Advancement of Science, 2015, pp. 21-63.

98. Campbell AC, Palmer MR, Klinkhammer GP, Bowers TS, Edmond JM, Lawrence JR, et al. Chemistry of hot springs on the Mid-Atlantic Ridge. Nature. 1988;335 (6190):514-519.

99. Conway TM, John SG. Quantification of dissolved iron sources to the North Atlantic Ocean. Nature. 2014;511(7508):212-215.

100. Resing JA, Sedwick PN, German CR, Jenkins WJ, Moffett JW, Sohst BM, et al. Basin-scale transport of hydrothermal dissolved metals across the South Pacific Ocean. Nature. 2015;523(7559):200-203.

101. McCollom TM. Observational, experimental, and theoretical constraints on carbon cycling in mid-ocean ridge hydrothermal systems. In: Lowell RP, Seewald JS, Metaxas A, Perfit MR, eds. Magma to Microbe: Modeling Hydrothermal Processes at Ocean Spreading Centers. Washington, DC: American Geophysical Union, 2008. pp. 193-213.

102. Pineau F, Javoy M. Carbon isotopes and concentrations in mid-ocean ridge basalts. Earth and Planetary Science Letters. 1983;62(2):239-257.

103. DesMarais DJ, Moore JG. Carbon and its isotopes in mid-ocean basaltic glasses. Earth and Planetary Science Letters. 1984;69(1):43-57.

104. Kroopnick PM. The distribution of C-13 of sigma- $\mathrm{CO}_{2}$ in the world ocean. Deep-Sea Research Part A - Oceanographic Research Papers. 1985;32(1):57-84.

105. Proskurowski G, Lilley MD, Brown TA. Isotopic evidence of magmatism and seawater bicarbonate removal at the endeavour hydrothermal system. Earth and Planetary Science Letters. 2004;225(1-2):53-61.

106. Alt JC, Teagle DAH. Hydrothermal alteration of upper oceanic crust formed at a fastspreading ridge: mineral, chemical, and isotopic evidence from ODP Site 801. Chemical Geology. 2003;201(3-4):191-211.

107. Eickmann B, Bach W, Rosner M, Peckmann J. Geochemical constraints on the modes of carbonate precipitation in peridotites from the Logatchev Hydrothermal Vent Field and Gakkel Ridge. Chemical Geology. 2009;268(1-2):97-106.

108. Beaupre SR, Druffel ERM. Constraining the propagation of bomb-radiocarbon through the dissolved organic carbon (DOC) pool in the northeast Pacific Ocean. Deep-Sea Research Part I - Oceanographic Research Papers. 2009;56(10):1717-1726.

109. Reeves EP, McDermott JM, Seewald JS. The origin of methanethiol in midocean ridge hydrothermal fluids. Proceedings of the National Academy of Sciences of the United States of America. 2014;111(15):5474-5479.

110. Riedel M, Collett TS, Malone M, Scientists E. Expedition 311 synthesis: scientific findings. Proceedings of the Integrated Ocean Drilling Program. 2006;311:2.

111. Von Damm KL, Lilley MD. Diffuse flow hydrothermal fluids from 9-degrees 50’ N East Pacific Rise: origin, evolution and biogeochemical controls. In: William 
SDW, Edward FD, Deborah SK, John AB, Craig SC, eds. The Subseafloor Biosphere at Mid-Ocean Ridges. Geophysical Monograph Series 144. Washington, DC: American Geophysical Union, 2004, pp. 245-268.

112. Proskurowski G, Lilley MD, Seewald JS, Früh-Green GL, Olson EJ, Lupton JE, et al. Abiogenic hydrocarbon production at Lost City hydrothermal field. Science. 2008;319(5863):604-607.

113. Yucel M, Luther GW. Temporal trends in vent fluid iron and sulfide chemistry following the 2005/2006 eruption at East Pacific Rise, 9 degrees 50' N. Geochemistry, Geophysics, Geosystems. 2013;14(4):759-765.

114. Butterfield DA, Massoth GJ, McDuff RE, Lupton JE, Lilley MD. Geochemistry of hydrothermal fluids from Axial Seamount hydrothermal emissions study vent field, Juan de Fuca Ridge - subseafloor boiling and subsequent fluid-rock interaction. Journal of Geophysical Research - Solid Earth and Planets. 1990;95(B8): 12895-12921.

115. Butterfield DA, Roe KK, Lilley MD, Huber JA, Baross JA, Embley RW, et al. Mixing, reaction and microbial activity in the sub-seafloor revealed by temporal and spatial variation in diffuse flow vents at Axial Volcano. Subseafloor Biosphere at Mid-Ocean Ranges. 2004;144:269-289.

116. Lang SQ, Butterfield DA, Lilley MD, Johnson HP, Hedges JI. Dissolved organic carbon in ridge-axis and ridge-flank hydrothermal systems. Geochimica et Cosmochimica Acta. 2006;70(15):3830-3842.

117. Charlou JL, Donval JP. Hydrothermal methane venting between 12-degrees-N and 26-degrees-N along the Mid-Atlantic Ridge. Journal of Geophysical Research Solid Earth. 1993;98(B6):9625-9642.

118. Charlou JL, Donval JP, Jean-Baptiste P, Dapoigny A, Rona PA. Gases and helium isotopes in high temperature solutions sampled before and after ODP Leg 158 drilling at TAG hydrothermal field (26N MAR). Geophysical Research Letters. 1996;23:3491-3494.

119. Charlou JL, Donval JP, Konn C, Ondreas H, Fouquet Y, Jean-Baptiste P, et al. High production and fluxes of $\mathrm{H}_{2}$ and $\mathrm{CH}_{4}$ and evidence of abiotic hydrocarbon synthesis by serpentinization in ultramafic-hosted hydrothermal systems on the Mid-Atlantic Ridge. In: Rona PA, ed. Diversity of Hydrothermal Systems on Slow Spreading Ocean Ridges. Geophysical Monograph Series 188. Washingon, DC: American Geophysical Union, 2010, pp. 265-296.

120. Proskurowski G, Lilley MD, Olson EJ. Stable isotopic evidence in support of active microbial methane cycling in low-temperature diffuse flow vents at 9 degrees 50, N East Pacific Rise. Geochimica et Cosmochimica Acta. 2008;72(8):2005-2023.

121. McCarthy M, Beaupre S, Walker B, Voparil I, Guilderson T, Druffel E. Chemosynthetic origin of C-14-depleted dissolved organic matter in a ridge-flank hydrothermal system. Nature Geoscience. 2011;4(1):32-36.

122. Haberstroh PR, Karl DM. Dissolved free amino-acids in hydrothermal vent habitats of the Guaymas Basin. Geochimica et Cosmochimica Acta. 1989;53(11):2937-2945.

123. Von Damm KL. Seafloor hydrothermal activity: black smoker chemistry and chimneys. Annual Review of Earth and Planetary Sciences. 1990;18:173-204.

124. Lin HT, Amend JP, LaRowe DE, Bingham JP, Cowen JP. Dissolved amino acids in oceanic basaltic basement fluids. Geochimica et Cosmochimica Acta. 2015;164: 175-190.

125. Lin Y, Koch B, Feseker T, Ziervogel K, Goldhammer T, Schmidt F, et al. Nearsurface heating of young rift sediment causes mass production and discharge of reactive dissolved organic matter. Scientific Reports. 2017;7:44864. 
126. McKay L, Klokman VW, Mendlovitz HP, LaRowe DE, Hoer DR, Albert D, et al. Thermal and geochemical influences on microbial biogeography in the hydrothermal sediments of Guaymas Basin, Gulf of California. Environmental Microbiology Reports. 2016;8(1):150-161.

127. Cruse AM, Seewald JS. Geochemistry of low-molecular weight hydrocarbons in hydrothermal fluids from Middle Valley, northern Juan de Fuca Ridge. Geochimica et Cosmochimica Acta. 2006;70(8):2073-2092.

128. Wheat C, Mottl M, Fisher A, Kadko D, Davis E, Baker E. Heat flow through a basaltic outcrop on a sedimented young ridge flank. Geochemistry, Geophysics, Geosystems. 2004;5:Q12006.

129. Wheat CG, Hulme SM, Fisher AT, Orcutt BN, Becker K. Seawater recharge into oceanic crust: IODP Exp 327 Site U1363 Grizzly Bare outcrop. Geochemistry, Geophysics, Geosystems. 2013;14(6):1957-1972.

130. Walker BD, McCarthy MD, Fisher AT, Guilderson TP. Dissolved inorganic carbon isotopic composition of low-temperature axial and ridge-flank hydrothermal fluids of the Juan de Fuca Ridge. Marine Chemistry. 2008;108(1-2):123-136.

131. Lin HT, Cowen JP, Olson EJ, Amend JP, Lilley MD. Inorganic chemistry, gas compositions and dissolved organic carbon in fluids from sedimented young basaltic crust on the Juan de Fuca Ridge flanks. Geochimica et Cosmochimica Acta. 2012;85:213-227.

132. Lin HT, Cowen JP, Olson EJ, Lilley MD, Jungbluth SP, Wilson ST, et al. Dissolved hydrogen and methane in the oceanic basaltic biosphere. Earth and Planetary Science Letters. 2014;405:62-73.

133. Lin H-T, Repeta DJ, Xu L, Rappe MS. Selective removal of isotopically enriched dissolved organic carbon from basalt-hosted deep subseafloor fluids of the Juan de Fuca Ridge. Earth and Planetary Science Letters. 2019;513:156-165.

134. Meyer JL, Jaekel U, Tully BJ, Glazer BT, Wheat CG, Lin HT, et al. A distinct and active bacterial community in cold oxygenated fluids circulating beneath the western flank of the Mid-Atlantic ridge. Scientific Reports. 2016;6:22541.

135. Walter SRS, Jaekel U, Osterholz H, Fisher AT, Huber JA, Pearson A, et al. Microbial decomposition of marine dissolved organic matter in cool oceanic crust. Nature Geoscience. 2018;11(5):334-339.

136. McDermott JM, Seewald JS, German CR, Sylva SP. Pathways for abiotic organic synthesis at submarine hydrothermal fields. Proceedings of the National Academy of Sciences of the United States of America. 2015;112(25):7668-7672.

137. Douville E, Charlou JL, Oelkers EH, Bienvenu P, Colon CFJ, Donval JP, et al. The rainbow vent fluids (36 degrees 14' N, MAR): the influence of ultramafic rocks and phase separation on trace metal content in Mid-Atlantic Ridge hydrothermal fluids. Chemical Geology. 2002;184(1-2):37-48.

138. Charlou JL, Donval JP, Fouquet Y, Jean-Baptiste P, Holm N. Geochemistry of high $\mathrm{H}_{2}$ and $\mathrm{CH}_{4}$ vent fluids issuing from ultramafic rocks at the Rainbow hydrothermal field (36 degrees 14' N, MAR). Chemical Geology. 2002;191(4):345-359.

139. Jean-Baptiste P, Fourre E, Charlou JL, German CR, Radford-Knoery J. Helium isotopes at the Rainbow hydrothermal site (Mid-Atlantic Ridge, 36 degrees 14' N). Earth and Planetary Science Letters. 2004;221(1-4):325-335.

140. Kelley DS, Karson JA, Früh-Green GL, Yoerger DR, Shank TM, Butterfield DA, et al. A serpentinite-hosted ecosystem: the Lost City hydrothermal field. Science. 2005;307(5714):1428-1434. 
141. Lang SQ, Butterfield DA, Schulte M, Kelley DS, Lilley MD. Elevated concentrations of formate, acetate and dissolved organic carbon found at the Lost City hydrothermal field. Geochimica et Cosmochimica Acta. 2010;74(3):941-952.

142. Lang SQ, Früh-Green GL, Bernasconi SM, Butterfield DA. Sources of organic nitrogen at the serpentinite-hosted Lost City hydrothermal field. Geobiology. 2013;11(2):154-169.

143. Seyfried WE, Pester NJ, Tutolo BM, Ding K. The Lost City hydrothermal system: constraints imposed by vent fluid chemistry and reaction path models on subseafloor heat and mass transfer processes. Geochimica et Cosmochimica Acta. 2015;163:59-79.

144. Reeves EP, Seewald JS, Saccocia P, Bach W, Craddock PR, Shanks WC, et al. Geochemistry of hydrothermal fluids from the PACMANUS, Northeast Pual and Vienna Woods hydrothermal fields, Manus Basin, Papua New Guinea. Geochimica et Cosmochimica Acta. 2011;75(4):1088-1123.

145. Sakai H, Gamo T, Kim ES, Tsutsumi M, Tanaka T, Ishibashi J, et al. Venting of carbon-dioxide rich fluid and hydrate formation in Mid-Okinawa Trough Backarc Basin. Science. 1990;248(4959):1093-1096.

146. Ishibashi J, Sano Y, Wakita H, Gamo T, Tsutsumi M, Sakai H. Helium and carbon geochemistry of hydrothermal fluids from the Mid-Okinawa Trough Back-arc Basin, southwest of Japan. Chemical Geology. 1995;123(1-4):1-15.

147. Welhan JA, Craig H. Methane, hydrogen and helium in hydrothermal fluids at $21 \mathrm{~N}$ on the East Pacific Rise. In: Rona PA, ed. Hydrothermal Processes at Seafloor Spreading Centers. New York: Plenum, 1983, pp. 391-409.

148. Lilley MD, Baross JA, Gordon LI. Reduced gases and bacteria in hydrothermal fluids: the Galapagos Spreading Center and 21 deg N East Pacific Rise. In: Rona PA, Bostrom K, Leubier L, Smith Jr. KL, eds. Hydrothermal Processes at Seafloor Spreading Centers. New York: Plenum, 1983, pp. 411-449.

149. Evans WC, White LD, Rapp JB. Geochemistry of some gases in hydrothermal fluids from the southern Juan-de-Fuca-Ridge. Journal of Geophysical Research - Solid Earth and Planets. 1988;93(B12):15305-15313.

150. Merlivat L, Pineau F, Javoy M. Hydrothermal vent waters at 13-degrees-N on the East Pacific Rise - isotopic composition and gas concentration. Earth and Planetary Science Letters. 1987;84(1):100-108.

151. Jeanbaptiste P, Charlou JL, Stievenard M, Donval JP, Bougault H, Mevel C. Helium and methane measurements in hydrothermal fluids from the Mid-Atlantic Ridge the Snake Pit Site at 23-degrees-N. Earth and Planetary Science Letters. 1991;106 (1-4):17-28.

152. James RH, Elderfield H, Palmer MR. The chemistry of hydrothermal fluids from the Broken Spur Site, 29-degrees-N Mid-Atlantic Ridge. Geochimica et Cosmochimica Acta. 1995;59(4):651-659.

153. Lein AY, Grichuk DV, Gurvich EG, Bogdanov YA. A new type of hydrogen- and methane-rich hydrothermal solutions in the rift zone of the Mid-Atlantic Ridge. Doklady Earth Sciences. 2000;375(9):1391-1394.

154. Martens CS. Generation of short chain organic-acid anions in hydrothermally altered sediments of the Guaymas Basin, Gulf of California. Applied Geochemistry. 1990;5:71-76.

155. Hawkes JA, Rossel PE, Stubbins A, Butterfield D, Connelly DP, Achterberg EP, et al. Efficient removal of recalcitrant deep-ocean dissolved organic matter during hydrothermal circulation. Nature Geoscience. 2015;8(11):856-860. 
156. Wellsbury P, Goodman K, Barth T, Cragg B, Barnes S, Parkes R. Deep marine biosphere fuelled by increasing organic matter availability during burial and heating. Nature. 1997;388(6642):573-576.

157. Seewald JS, Seyfried WE, Thornton EC. Organic-rich sediment alteration - an experimental and theoretical study at elevated temperatures and pressures. Applied Geochemistry. 1990;5:193-209.

158. McCollom TM, Shock EL. Geochemical constraints on chemolithoautotrophic metabolism by microorganisms in seafloor hydrothermal systems. Geochimica et Cosmochimica Acta. 1997;61(20):4375-4391.

159. Takai K, Nakamura K, Toki T, Tsunogai U, Miyazaki M, Miyazaki J, et al. Cell proliferation at 122 degrees $\mathrm{C}$ and isotopically heavy $\mathrm{CH}_{4}$ production by a hyperthermophilic methanogen under high-pressure cultivation. Proceedings of the National Academy of Sciences of the United States of America. 2008;105 (31):10949-10954.

160. Karl DM, Wirsen CO, Jannasch HW. Deep-sea primary production at the Galapagos hydrothermal vents. Science. 1980;207(4437):1345-1347.

161. Edwards KJ, Becker K, Colwell F. The deep, dark energy biosphere: intraterrestrial life on Earth. Annual Review of Earth and Planetary Sciences. 2012;40:551-568.

162. Wankel SD, Germanovich LN, Lilley MD, Genc G, DiPerna CJ, Bradley AS, et al. Influence of subsurface biosphere on geochemical fluxes from diffuse hydrothermal fluids. Nature Geoscience. 2011;4(7):461-468.

163. Mottl MJ. Partitioning of energy and mass fluxes between mid-ocean ridge axes and flanks at high and low temperature. In: Halbach PE, Tunnicliffe V, Hein JR, eds. Energy and Mass Transfer in Marine Hydrothermal Systems. Berlin: Dahlem University Press, 2003, pp. 271-286.

164. Wheat CG, Fisher AT, McManus J, Hulme SM, Orcutt BN. Cool seafloor hydrothermal springs reveal global geochemical fluxes. Earth and Planetary Science Letters. 2017;476:179-188.

165. Elderfield H, Wheat CG, Mottl MJ, Monnin C, Spiro B. Fluid and geochemical transport through oceanic crust: a transect across the eastern flank of the Juan de Fuca Ridge. Earth and Planetary Science Letters. 1999;172(1-2):151-165.

166. Mottl MJ, Wheat G, Baker E, Becker N, Davis E, Feely R, et al. Warm springs discovered on 3.5 Ma oceanic crust, eastern flank of the Juan de Fuca Ridge. Geology. 1998;26(1):51-54.

167. Sansone FJ, Mottl MJ, Olson EJ, Wheat CG, Lilley MD. $\mathrm{CO}_{2}$-depleted fluids from mid-ocean ridge-flank hydrothermal springs. Geochimica et Cosmochimica Acta. 1998;62(13):2247-2252.

168. Maloszewski $\mathrm{P}$, Zuber A. Influence of matrix diffusion and exchange-reactions on radiocarbon ages in fissured carbonate aquifers. Water Resources Research. 1991;27 (8):1937-1945.

169. Bethke CM, Johnson TM. Paradox of groundwater age. Geology. 2002;30 (2):107-110.

170. Bethke CM, Johnson TM. Groundwater age and groundwater age dating. Annual Review of Earth and Planetary Sciences. 2008;36:121-152.

171. Rona PA, Widenfalk L, Bostrom K. Serpentinized ultramafics and hydrothermal activity at the Mid-Atlantic Ridge crest near 15-degrees-N. Journal of Geophysical Research - Solid Earth and Planets. 1987;92(B2):1417-1427.

172. Charlou JL, Bougault H, Appriou P, Jeanbaptiste P, Etoubleau J, Birolleau A. Water column anomalies associated with hydrothermal activity between 11-degrees-40' and 
13-degrees-N on the east pacific rise - discrepancies between tracers. Deep-Sea Research Part A - Oceanographic Research Papers. 1991;38(5):569-596.

173. Rona PA, Bougault H, Charlou JL, Appriou P, Nelsen TA, Trefry JH, et al. Hydrothermal circulation, serpentinization, and degassing at a rift-valley fracture-zone intersection - Mid-Atlantic Ridge near 15-degrees-N, 45-degrees-W. Geology. 1992;20(9):783-786.

174. Schrenk MO, Brazelton WJ, Lang SQ. Serpentinization, carbon, and deep life. In: Hazen RM, Jones AP, Baross JA, eds. Carbon in Earth. Reviews in Mineralogy \& Geochemistry. 75. Chantilly: Mineralogical Society of America, 2013, pp. 575-606.

175. German CR, Bowen A, Coleman ML, Honig DL, Huber JA, Jakuba MV, et al. Diverse styles of submarine venting on the ultraslow spreading Mid-Cayman Rise. Proceedings of the National Academy of Sciences of the United States of America. 2010;107(32):14020-14025.

176. Haggerty JA. Evidence from fluid seeps atop serpentine seamounts in the mariana fore-arc - clues for emplacement of the seamounts and their relationship to fore-arc tectonics. Marine Geology. 1991;102(1-4):293-309.

177. Kelley DS, Karson JA, Blackman DK, Früh-Green GL, Butterfield DA, Lilley MD, et al. An off-axis hydrothermal vent field near the Mid-Atlantic Ridge at 30 degrees N. Nature. 2001;412(6843):145-149.

178. Monnin C, Chavagnac V, Boulart C, Menez B, Gerard M, Gerard E, et al. Fluid chemistry of the low temperature hyperalkaline hydrothermal system of Prony Bay (New Caledonia). Biogeosciences. 2014;11(20):5687-5706.

179. Ohara Y, Reagan MK, Fujikura K, Watanabe H, Michibayashi K, Ishii T, et al. A serpentinite-hosted ecosystem in the Southern Mariana Forearc. Proceedings of the National Academy of Sciences of the United States of America. 2012;109(8):2831-2835.

180. Konn C, Charlou JL, Holm NG, Mousis O. The production of methane, hydrogen, and organic compounds in ultramafic-hosted hydrothermal vents of the Mid-Atlantic Ridge. Astrobiology. 2015;15(5):381-399.

181. Bonatti E, Lawrence JR, Hamlyn PR, Breger D. Aragonite from deep-sea ultramafic rocks. Geochimica et Cosmochimica Acta. 1980;44(8):1207-1214.

182. Keir RS. A note on the fluxes of abiogenic methane and hydrogen from mid-ocean ridges. Geophysical Research Letters. 2010;37:L24609.

183. McCollom TM, Seewald JS. Abiotic synthesis of organic compounds in deep-sea hydrothermal environments. Chemical Reviews. 2007;107(2):382-401.

184. Wang DT, Reeves EP, McDermott JM, Seewald JS, Ono S. Clumped isotopologue constraints on the origin of methane at seafloor hot springs. Geochimica et Cosmochimica Acta. 2018;223:141-158.

185. Kelley DS, Früh-Green GL. Abiogenic methane in deep-seated mid-ocean ridge environments: insights from stable isotope analyses. Journal of Geophysical Research - Solid Earth. 1999;104(B5):10439-10460.

186. Kelley DS, Früh-Green GL. Volatile lines of descent in submarine plutonic environments: insights from stable isotope and fluid inclusion analyses. Geochimica et Cosmochimica Acta. 2001;65(19):3325-3346.

187. Bradley AS, Summons RE. Multiple origins of methane at the Lost City hydrothermal field. Earth and Planetary Science Letters. 2010;297(1-2):34-41.

188. Pisapia C, Gerard E, Gerard M, Lecourt L, Lang SQ, Pelletier B, et al. Mineralizing filamentous bacteria from the Prony Bay hydrothermal field give new insights into the functioning of serpentinization-based subseafloor ecosystems. Frontiers in Microbiology. 2017;8:18. 
189. Lang SQ, Früh-Green GL, Bernasconi SM, Brazelton WJ, Schrenk MO, McGonigle JM. Deeply-sourced formate fuels sulfate reducers but not methanogens at Lost City hydrothermal field. Scientific Reports. 2018;8:755.

190. Kawka OE, Simoneit BRT. Survey of hydrothermally-generated petroleums from the Guaymas Basin spreading center. Organic Geochemistry. 1987;11(4): 311-328.

191. Kadko D, Baross J, Alt J. The magnitude and global implications of hydrothermal flux. In: Humphris SE, Zierenberg RA, Mullineaux LS, Thomson RE, eds. Seafloor Hydrothermal Systems: Physical, Chemical, Biological, and Geological Interactions. Geophysical Monograph Series. Washington, DC: American Geophysical Union, 1995, pp. 446-466.

192. Saal AE, Hauri EH, Langmuir CH, Perfit MR. Vapour undersaturation in primitive mid-ocean-ridge basalt and the volatile content of Earth's upper mantle. Nature. 2002;419(6906):451-455.

193. Staudigel H, Hart SR, Schmincke HU, Smith BM. Cretaceous ocean crust at DSDP Site-417 and Site-418 - carbon uptake from weathering versus loss by magmatic outgassing. Geochimica et Cosmochimica Acta. 1989;53(11):3091-3094.

194. Alt JC, Teagle DAH. The uptake of carbon during alteration of ocean crust. Geochimica et Cosmochimica Acta. 1999;63(10):1527-1535.

195. Schwarzenbach EM, Lang SQ, Frah-Green GL, Lilley MD, Bemasconi SM, Mehay S. Sources and cycling of carbon in continental, serpentinite-hosted alkaline springs in the Voltri Massif, Italy. Lithos. 2013;177:226-244.

196. Alt JC, Schwarzenbach EM, Frueh-Green GL, Shanks WC, Bernasconi SM, Garrido $\mathrm{CJ}$, et al. The role of serpentinites in cycling of carbon and sulfur: seafloor serpentinization and subduction metamorphism. Lithos. 2013;178:40-54.

197. Simoneit BRT, Lonsdale PF. Hydrothermal petroleum in mineralized mounds at the seabed of Guaymas Basin. Nature. 1982;295(5846):198-202.

198. Kvenvolden KA, Simoneit BRT. Hydrothermally derived petroleum - examples from Guaymas Basin, Gulf of California, and Escanaba Trough, northeast PacificOcean. AAPG Bulletin - American Association of Petroleum Geologists. 1990;74(3): 223-237.

199. Tissot BP, Welte DH. Petroleum Formation and Occurrence. Berlin: Springer, 1984.

200. Tissot B, Espitalie J. Thermal evolution of organic-matter in sediments - application of a mathematical simulation - petroleum potential of sedimentary basins and reconstructing thermal history of sediments. Revue De L Institut Francais Du Petrole. 1975;30(5):743-777.

201. Lewan MD, Winters JC, McDonald JH. Generation of oil-like pyrolyzates from organic-rich shales. Science. 1979;203(4383):897-899.

202. Seewald JS. Aqueous geochemistry of low molecular weight hydrocarbons at elevated temperatures and pressures: constraints from mineral buffered laboratory experiments. Geochimica et Cosmochimica Acta. 2001;65(10):1641-1664.

203. Shock EL, Canovas P, Yang ZM, Boyer G, Johnson K, Robinson K, et al. Thermodynamics of organic transformations in hydrothermal fluids. Thermodynamics of Geothermal Fluids. 2013;76:311-350.

204. Simoneit BRT. Hydrothermal petroleum - genesis, migration, and deposition in Guaymas Basin, Gulf of California. Canadian Journal of Earth Sciences. 1985; 22(12):1919-1929.

205. Didyk BM, Simoneit BRT. Hydrothermal oil of Guaymas Basin and implications for petroleum formation mechanisms. Nature. 1989;342(6245):65-69. 
206. Rushdi AI, Simoneit BRT. Condensation reactions and formation of amides, esters, and nitriles under hydrothermal conditions. Astrobiology. 2004;4(2):211-224.

207. Simoneit B, Lein A, Peresypkin V, Osipov G. Composition and origin of hydrothermal petroleum and associated lipids in the sulfide deposits of the Rainbow Field (Mid-Atlantic Ridge at 36 degrees N). Geochimica et Cosmochimica Acta. 2004;68(10):2275-2294.

208. Parkes RJ, Taylor J, Jorckramberg D. Demonstration, using Desulfobacter sp., of 2 pools of acetate with different biological availabilities in marine pore water. Marine Biology. 1984;83(3):271-276.

209. Simoneit BRT, Kawka OE, Brault M. Origin of gases and condensates in the Guaymas Basin hydrothermal system (Gulf of California). Chemical Geology. 1988;71(1-3):169-182.

210. Murdoch LC, Germanovich LN, Wang H, Onstott TC, Elsworth D, Stetler L, et al. Hydrogeology of the vicinity of Homestake mine, South Dakota, USA. Hydrogeology Journal. 2012;20(1):27-43.

211. Holland G, Lollar BS, Li L, Lacrampe-Couloume G, Slater GF, Ballentine CJ. Deep fracture fluids isolated in the crust since the Precambrian era. Nature. 2013;497 (7449):357-360.

212. Pedersen K. Exploration of deep intraterrestrial microbial life: current perspectives. FEMS Microbiology Letters. 2000;185(1):9-16.

213. Colwell FS, D'Hondt S. Nature and extent of the deep biosphere. Carbon in Earth. 2013;75:547-574.

214. Huber H, Huber R, Lüdemann H-D, Stetter KO. Search for hyperhermophilic microorganisms in fluids obtained from the KTB pump test. Scientific Drilling. 1994;4:127-129.

215. Whitman WB, Coleman DC, Wiebe WJ. Prokaryotes: the unseen majority. Proceedings of the National Academy of Sciences of the United States of America. 1998; 95(12):6578-6583.

216. Kallmeyer J, Pockalny R, Adhikari RR, Smith DC, D'Hondt S. Global distribution of microbial abundance and biomass in subseafloor sediment. Proceedings of the National Academy of Sciences of the United States of America. 2012;109 (40):16213-16216.

217. McMahon S, Parnell J. Weighing the deep continental biosphere. FEMS Microbiology Ecology. 2014;87(1):113-120.

218. Fredrickson JK, Onstott TC, eds. Biogeochemical and Geological Significance of Subsurface Microbiology. New York: Wiley-Liss, 2001.

219. Sahl JW, Schmidt RH, Swanner ED, Mandernack KW, Templeton AS, Kieft TL, et al. Subsurface microbial diversity in deep-granitic-fracture water in Colorado. Applied and Environmental Microbiology. 2008;74(1):143-152.

220. Chivian D, Brodie EL, Alm EJ, Culley DE, Dehal PS, DeSantis TZ, et al. Environmental genomics reveals a single-species ecosystem deep within earth. Science. 2008;322(5899):275-278.

221. Osburn MR, LaRowe DE, Momper LM, Amend JP. Chemolithotrophy in the continental deep subsurface: Sanford Underground Research Facility (SURF), USA. Frontiers in Microbiology. 2014;5:610.

222. Probst AJ, Castelle CJ, Singh A, Brown CT, Anantharaman K, Sharon I, Hug LA, Burstein D, Emerson JB, Thomas BC, Banfield JF. Genomic resolution of a cold subsurface aquifer community provides metabolic insights for novel microbes adapted to high $\mathrm{CO}_{2}$ concentrations. Environmental Microbiology. 2016;19:459-474. 
223. Stevens TO, McKinley JP. Lithoautotrophic microbial ecosystems in deep basalt aquifers. Science. 1995;270(5235):450-454.

224. Veto I, Futo I, Horvath I, Szanto Z. Late and deep fermentative methanogenesis as reflected in the $\mathrm{H}-\mathrm{C}-\mathrm{O}-\mathrm{S}$ isotopy of the methane-water system in deep aquifers of the Pannonian Basin (SE Hungary). Organic Geochemistry. 2004;35(6):713-723.

225. Fredrickson JK, Balkwill DL. Geomicrobial processes and biodiversity in the deep terrestrial subsurface. Geomicrobiology Journal. 2006;23(6):345-356.

226. Lapworth DJ, Gooddy DC, Butcher AS, Morris BL. Tracing groundwater flow and sources of organic carbon in sandstone aquifers using fluorescence properties of dissolved organic matter (DOM). Applied Geochemistry. 2008;23(12):3384-3390.

227. Vetter A, Mangelsdorf K, Wolfgramm M, Rauppach K, Schettler G, Vieth-Hillebrand A. Variations in fluid chemistry and membrane phospholipid fatty acid composition of the bacterial community in a cold storage groundwater system during clogging events. Applied Geochemistry. 2012;27(6):1278-1290.

228. Grundger F, Jimenez N, Thielemann T, Straaten N, Luders W, Richnow HH, et al. Microbial methane formation in deep aquifers of a coal-bearing sedimentary basin, Germany. Frontiers in Microbiology. 2015;6:200.

229. Schloemer S, Elbracht J, Blumenberg M, Illing CJ. Distribution and origin of dissolved methane, ethane and propane in shallow groundwater of Lower Saxony, Germany. Applied Geochemistry. 2016;67:118-132.

230. Bell RA, Darling WG, Ward RS, Basava-Reddi L, Halwa L, Manamsa K, et al. A baseline survey of dissolved methane in aquifers of Great Britain. Science of the Total Environment. 2017;601:1803-1813.

231. Murphy EM, Schramke JA, Fredrickson JK, Bledsoe HW, Francis AJ, Sklarew DS, et al. The influence of microbial activity and sedimentary organic-carbon on the isotope geochemistry of the middendorf aquifer. Water Resources Research. 1992;28(3):723-740.

232. Means JL, Hubbard N. Short-chain aliphatic acid anions in deep subsurface brines - a review of their origin, occurrence, properties, and importance of new data on their distribution and geochemical implications in the paleo-duro-basin, Texas. Organic Geochemistry. 1987;11(3):177-191.

233. Lundegard PD, Kharaka YK, eds. Distribution and Occurrence of Organic Acids in Subsurface Waters. Berlin: Springer, 1994.

234. Aitken CM, Jones DM, Larter SR. Anaerobic hydrocarbon biodegradation in deep subsurface oil reservoirs. Nature. 2004;431(7006):291-294.

235. Strapoc D, Mastalerz M, Dawson K, Macalady J, Callaghan AV, Wawrik B, et al. Biogeochemistry of microbial coal-bed methane. Annual Review of Earth and Planetary Sciences. 2011;39:617-656.

236. Pedersen K. Diversity and activity of microorganisms in deep igneous rock aquifers of the Fennoscandian Shield. In: Fredrickson JK, Fletcher M, eds. Subsurface Microbiology and Biogeochemistry, New York: Wiley-Liss, 2001, pp. 97-139.

237. Amend JP, Teske A. Expanding frontiers in deep subsurface microbiology. Palaeogeography, Palaeoclimatology, Palaeoecology. 2005;219(1-2):131-155.

238. Lollar BS, Onstott TC, Lacrampe-Couloume G, Ballentine CJ. The contribution of the Precambrian continental lithosphere to global $\mathrm{H}_{2}$ production. Nature. 2014;516(7531):379-382.

239. Boston PJ, Spilde MN, Northup DE, Melim LA, Soroka DS, Kleina LG, et al. Cave biosignature suites: microbes, minerals, and Mars. Astrobiology. 2001;1(1):25-55. 
240. Northup DE, Lavoie KH. Geomicrobiology of caves: a review. Geomicrobiology Journal. 2001;18(3):199-222.

241. Barton HA, Northup DE. Geomicrobiology in cave environments: past, current and future perspectives. Journal of Cave and Karst Studies. 2007;69(1):163-178.

242. Suzuki S, Ishii S, Wu A, Cheung A, Tenney A, Wanger G, et al. Microbial diversity in The Cedars, an ultrabasic, ultrareducing, and low salinity serpentinizing ecosystem. Proceedings of the National Academy of Sciences of the United States of America. 2013;110(38):15336-15341.

243. Magnabosco C, Tekere M, Lau MCY, Linage B, Kuloyo O, Erasmus M, et al. Comparisons of the composition and biogeographic distribution of the bacterial communities occupying South African thermal springs with those inhabiting deep subsurface fracture water. Frontiers in Microbiology. 2014;5:679.

244. Baker MA, Valett HM, Dahm CN. Organic carbon supply and metabolism in a shallow groundwater ecosystem. Ecology. 2000;81(11):3133-3148.

245. Kotelnikova S. Microbial production and oxidation of methane in deep subsurface. Earth-Science Reviews. 2002;58(3-4):367-395.

246. Fry NK, Fredrickson JK, Fishbain S, Wagner M, Stahl DA. Population structure of microbial communities associated with two deep, anaerobic, alkaline aquifers. Applied and Environmental Microbiology. 1997;63(4):1498-1504.

247. Vieth A, Mangelsdorf K, Sykes R, Horsfield B. Water extraction of coals - potential for estimating low molecular weight organic acids as carbon feedstock for the deep terrestrial biosphere. Organic Geochemistry. 2008;39(8):985-991.

248. Simkus DN, Slater GF, Lollar BS, Wilkie K, Kieft TL, Magnabosco C, et al. Variations in microbial carbon sources and cycling in the deep continental subsurface. Geochimica et Cosmochimica Acta. 2016;173:264-283.

249. Lau MCY, Kieft TL, Kuloyo O, Linage-Alvarez B, Van Heerden E, Lindsay MR, et al. An oligotrophic deep-subsurface community dependent on syntrophy is dominated by sulfur-driven autotrophic denitrifiers. Proceedings of the National Academy of Sciences of the United States of America. 2016;113(49):E7927-E7936.

250. Kieft TL, Walters CC, Higgins MB, Mennito AS, Clewett CFM, Heuer V, et al. Dissolved organic matter compositions in 0.6-3.4 km deep fracture waters, Kaapvaal Craton, South Africa. Organic Geochemistry. 2018;118:116-131.

251. Stevens T. Lithoautotrophy in the subsurface. FEMS Microbiology Reviews. 1997;20 (3-4):327-337.

252. Longnecker K, Kujawinski EB. Composition of dissolved organic matter in groundwater. Geochimica et Cosmochimica Acta. 2011;75(10):2752-2761.

253. Chapelle FH, O’Neill K, Bradley PM, Methe BA, Ciufo SA, Knobel LL, et al. A hydrogen-based subsurface microbial community dominated by methanogens. Nature. 2002;415(6869):312-315.

254. Griebler C, Lueders T. Microbial biodiversity in groundwater ecosystems. Freshwater Biology. 2009;54(4):649-677.

255. Flynn TM, Sanford RA, Ryu H, Bethke CM, Levine AD, Ashbolt NJ, et al. Functional microbial diversity explains groundwater chemistry in a pristine aquifer. $B M C$ Microbiology. 2013;13:146.

256. Probst AJ, Ladd B, Jarett JK, Geller-McGrath DE, Sieber CMK, Emerson JB, et al. Differential depth distribution of microbial function and putative symbionts through sediment-hosted aquifers in the deep terrestrial subsurface. Nature Microbiology. 2018;3(3):328-336. 
257. Leenheer JA, Malcolm RL, McKinley PW. Occurrence of dissolved organic carbon in selected ground-water samples in the United States. Journal of Research of the US Geological Survey. 1974;2:361-369.

258. McMahon PB, Chapelle FH. Microbial production of organic acids in aquitard sediments and its role in aquifer geochemistry. Nature. 1991;349(6306):233-235.

259. Kusel K, Totsche KU, Trumbore SE, Lehmann R, Steinhauser C, Herrmann M. How deep can surface signals be traced in the critical zone? Merging biodiversity with biogeochemistry research in a central German Muschelkalk landscape. Frontiers in Earth Science. 2016;4:32.

260. Head IM, Jones DM, Larter SR. Biological activity in the deep subsurface and the origin of heavy oil. Nature. 2003;426(6964):344-352.

261. Nazina TN, Shestakova NM, Ivoilov VS, Kostrukov NK, Belyaev SS, Ivanov MV. Radiotracer assay of microbial processes in petroleum reservoirs. Advances in Biotechnology \& Microbiology. 2017;2(4):1-9.

262. Magot M, Ollivier B, Patel BKC. Microbiology of petroleum reservoirs. Antonie Van Leeuwenhoek International Journal of General and Molecular Microbiology. 2000;77(2):103-116.

263. Larter S, Huan H, Adams J, Bennett B, Jokanola O, Oldenburg T, et al. The controls on the composition of biodegraded oils in the deep subsurface: part II - geological controls on subsurface biodegradation fluxes and constraints on reservoir-fluid property prediction. AAPG Bulletin. 2006;90(6):921-938.

264. Zhu YL, Vieth-Hillebrand A, Wilke FDH, Horsfield B. Characterization of watersoluble organic compounds released from black shales and coals. International Journal of Coal Geology. 2015;150:265-275.

265. Onstott TC, Lin LH, Davidson M, Mislowack B, Borcsik M, Hall J, et al. The origin and age of biogeochemical trends in deep fracture water of the Witwatersrand Basin, South Africa. Geomicrobiology Journal. 2006;23(6):369-414.

266. Kietavainen R, Ahonen L, Niinikoski P, Nykanen H, Kukkonen IT. Abiotic and biotic controls on methane formation down to $2.5 \mathrm{~km}$ depth within the Precambrian Fennoscandian Shield. Geochimica et Cosmochimica Acta. 2017;202:124-145.

267. Lollar BS, Voglesonger K, Lin LH, Lacrampe-Couloume G, Telling J, Abrajano TA, et al. Hydrogeologic controls on episodic $\mathrm{H}_{2}$ release from Precambrian fractured rocks - energy for deep subsurface life on Earth and Mars. Astrobiology. 2007;7 (6):971-986.

268. Suzuki Y, Konno U, Fukuda A, Komatsu DD, Hirota A, Watanabe K, et al. Biogeochemical signals from deep microbial life in terrestrial crust. PLoS One. 2014;9(12): e113063.

269. Suzuki S, Kuenen JG, Schipper K, van der Velde S, Ishii S, Wu A, et al. Physiological and genomic features of highly alkaliphilic hydrogen-utilizing Betaproteobacteria from a continental serpentinizing site. Nature Communications. 2014;5:3900.

270. Li L, Wing BA, Bui TH, McDermott JM, Slater GF, Wei S, et al. Sulfur massindependent fractionation in subsurface fracture waters indicates a long-standing sulfur cycle in Precambrian rocks. Nature Communications. 2016;7:13252.

271. Momper L, Jungbluth SP, Lee MD, Amend JP. Energy and carbon metabolisms in a deep terrestrial subsurface fluid microbial community. ISME Journal. 2017;11 (10):2319-2333.

272. Magnabosco C, Ryan K, Lau MCY, Kuloyo O, Lollar BS, Kieft TL, et al. A metagenomic window into carbon metabolism at $3 \mathrm{~km}$ depth in Precambrian continental crust. ISME Journal. 2016;10(3):730-741. 
273. Colman DR, Poudel S, Stamps BW, Boyd ES, Spear JR. The deep, hot biosphere: twenty-five years of retrospection. Proceedings of the National Academy of Sciences of the United States of America. 2017;114(27):6895-6903.

274. Jungbluth SP, del Rio TG, Tringe SG, Stepanauskas R, Rappe MS. Genomic comparisons of a bacterial lineage that inhabits both marine and terrestrial deep subsurface systems. PeerJ. 2017;5:e3134.

275. Lollar BS, Lacrampe-Couloume G, Slater GF, Ward J, Moser DP, Gihring TM, et al. Unravelling abiogenic and biogenic sources of methane in the Earth's deep subsurface. Chemical Geology. 2006;226(3-4):328-339.

276. Kadnikov VV, Frank YA, Mardanov AV, Beletskii AV, Ivasenko DA, Pimenov NV, et al. Uncultured bacteria and methanogenic archaea predominate in the microbial community of western Siberian deep subsurface aquifer. Microbiology. 2017;86 (3):412-415.

277. Momper L, Reese BK, Zinke L, Wanger G, Osburn MR, Moser D, et al. Major phylum-level differences between porefluid and host rock bacterial communities in the terrestrial deep subsurface. Environmental Microbiology Reports. 2017;9 (5):501-511.

278. Wanger G, Southam G, Onstott TC. Structural and chemical characterization of a natural fracture surface from 2.8 kilometers below land surface: biofilms in the deep subsurface. Geomicrobiology Journal. 2006;23(6):443-452.

279. Purkamo L, Bomberg M, Nyyssonen M, Kukkonen I, Ahonen L, Itavaara M. Heterotrophic communities supplied by ancient organic carbon predominate in deep fennoscandian bedrock fluids. Microbial Ecology. 2015;69(2):319-332.

280. Jangir Y, French S, Momper LM, Moser DP, Amend JP, El-Naggar MY. Isolation and characterization of electrochemically active subsurface Delftia and Azonexus species. Frontiers in Microbiology. 2016;7:756.

281. Lehman RM, Colwell FS, Bala GA. Attached and unattached microbial communities in a simulated basalt aquifer under fracture- and porous-flow conditions. Applied and Environmental Microbiology. 2001;67(6):2799-2809.

282. Petsch ST, Eglinton TI, Edwards KJ. ${ }^{14} \mathrm{C}$-dead living biomass: evidence for microbial assimilation of ancient organic carbon during share weathering. Science. 2001;292(5519):1127-1131. 